https://helda.helsinki.fi

\title{
Response of fungal and actinobacterial communities to water-level drawdown in boreal peatland sites
}

\section{Peltoniemi, Krista}

2009

Peltoniemi , K , Fritze , H \& Laiho , R 2009 , ' Response of fungal and actinobacterial communities to water-level drawdown in boreal peatland sites ' , Soil Biology \& Biochemistry , vol. 41 , no. 9 , pp. 1902-1914 . https://doi.org/10.1016/j.soilbio.2009.06.018

http://hdl.handle.net/10138/27409

https://doi.org/10.1016/j.soilbio.2009.06.018

acceptedVersion

Downloaded from Helda, University of Helsinki institutional repository.

This is an electronic reprint of the original article.

This reprint may differ from the original in pagination and typographic detail.

Please cite the original version. 
Published in Soil Biology \& Biochemistry, vol. 41, pages 1902-1914, 2009.

doi: 10.1016/j.soilbio.2009.06.018

\title{
Response of fungal and actinobacterial communities to water-level drawdown in boreal peatland sites
}

\author{
Krista Peltoniemi $^{\mathrm{a},{ }^{*}, \text { Hannu Fritze }}{ }^{\mathrm{a}}$, Raija Laiho ${ }^{\mathrm{b}}$ \\ ${ }^{a}$ Finnish Forest Research Institute, Vantaa Research Unit, P.O. Box 18, FI-01301 Vantaa, \\ Finland (krista.peltoniemi@metla.fi, hannu.fritze@metla.fi) \\ ${ }^{\mathrm{b}}$ Department of Forest Ecology, P.O. Box 27, University of Helsinki, FI-00014 Helsinki, \\ Finland (raija.laiho@ helsinki.fi)
}

\begin{abstract}
We used PCR-DGGE fingerprinting and direct sequencing to analyse the response of fungal and actinobacterial communities to changing hydrological conditions at 3 different sites in a boreal peatland complex in Finland. The experimental design involved a shortterm (3 yrs; STD) and a long-term (43 yrs; LTD) water-level drawdown. Correspondence analyses of DGGE bands revealed differences in the communities between natural sites representing the nutrient-rich mesotrophic fen, the nutrient-poorer oligotrophic fen, and the nutrient-poor ombrotrophic bog. Still, most fungi and actinobacteria found in the pristine peatland seemed robust to the environmental variables. Both fungal and actinobacterial diversity was higher in the fens than in the bog. Fungal diversity increased significantly after STD whereas actinobacterial diversity did not respond to hydrology. Both fungal and actinobacterial communities became more similar between peatland types after LTD, which was not apparent after STD. Most sequences clustered equally between the two main fungal phyla Ascomycota and Basidiomycota. Sequencing revealed that basidiomycetes may respond more (either positively or negatively) to hydrological changes than ascomycetes. Overall, our results suggest that fungal responses to waterlevel drawdown depend on peatland type. Actinobacteria seem to be less sensitive to hydrological changes, although the response of some may similarly depend on peatland type.
\end{abstract}

Keywords: Microbial community; Climate change; Fungi; Actinobacteria; Drainage; Fen; Bog; DGGE; CA 


\section{Introduction}

Peatlands represent the most important store of terrestrial carbon (C). Despite their importance in the global $\mathrm{C}$ cycle, microbial communities in peatlands are still poorly understood. Mapping the diversity of the different microbial groups in peatlands has just begun and the microbes involved in methane cycling, i.e., methanotrophic bacteria (e.g., Dedysh et al., 1998; Morris et al., 2002; Jaatinen et al., 2005; Raghoebarsing et al., 2005) and methanogenic archaea (e.g., Galand et al., 2002; Basiliko et al., 2003; Sizova et al., 2003), have been studied the most extensively. Bacterial diversity of peatlands has been explored with molecular methods in, e.g., Sphagnum bogs of New England (Morales et al., 2006), two drained fens in Slovenia (Kraigher et al., 2006), and a Sphagnum bog in western Siberia (Dedysh et al., 2006). The molecular studies have broadened our general view of the distribution of microbes in peatlands.

The response of microbial communities to a persistent decrease in the water-level is important to document, since this is the ultimate outcome in peatlands following drainage or climate warming. Comparative analysis of various peatland sites in the UK showed that even a short-term drought can change the microbial community and that any changes are dependent on peatland type and the microbial group (Kim et al. 2008). Peatlands sequester organic matter into the anoxic layer, but most of the $\mathrm{C}$ flux takes place in the often relatively thin oxic layers above the water level. Lowering the water level of a northern boreal fen is accompanied with coincided with an increased $\mathrm{CO}_{2}$ flux from peat to the atmosphere (Jaatinen et al., 2008). In oxic conditions, fungi are considered to be the principal decomposers (e.g., Thormann 2006a,b), although actinobacteria may contribute significantly to the decomposition of organic matter since they are mainly strict aerobes (Goodfellow and Williams, 1983) that can degrade polymers such as lignin, cellulose, pectin, and chitin as well as humic materials (McCarthy, 1987; Pankratov et al., 2006). In Russian peatlands, $30 \%$ of sequenced clones were most similar to Actinobacteria (Dedysh et al., 2006) and certain members of this group have been found to play a leading role in cellulose degradation (Pankratov et al., 2006).

Here, we study the fungal and actinobacterial communities of a boreal peatland complex with polymerase chain reaction-denaturing gradient gel electrophoresis (PCRDGGE) fingerprinting. We amplified $18 \mathrm{~S}$ and $16 \mathrm{~S}$ ribosomal DNA (rDNA) to study how the communities: i) differ among pristine sites with different vegetation and nutrient levels, and; ii) change following water-level drawdown. The sites covered the common peatland types in boreal Eurasia: two minerotrophic fens and an ombrotrophic bog exhibiting microtopographical variation as hummock, lawn level and hollow surfaces, and included a control (contemporary water-level regime) as well as two levels of hydrological manipulation. Results from our earlier work (Jaatinen et al., 2007) showed how both fungal and actinobacterial phospholipid fatty acid (PLFA) biomarkers responded to water-level drawdown, and fungal PLFAs were positively correlated with potential $\mathrm{CO}_{2}$ production in these sites, thus supporting our experimental rationale.

\section{Materials and methods}

\subsection{Site description and sampling}

Sampling was conducted at Lakkasuo peatland complex in central Finland ( $61^{\circ} 48 \mathrm{~N}$, $24^{\circ} 19$ E, ca. $150 \mathrm{~m}$ above sea level) on May 18, 2004. A detailed description of Lakkasuo and the study sites can be found elsewhere (Laine et al., 2004; Jaatinen et al., 2007). The 
study sites represented three different nutrient levels along a fen-bog gradient, each with a characteristic vegetation type: two minerotrophic fens; mesotrophic (ME; a relatively nutrient-rich "intermediate fen") and oligotrophic (OL, "poor fen"), and an ombrotrophic bog (OM; nutrient-poor) (hereafter referred to as nutrient levels; see Table 1 for surface peat nutrient concentrations and $\mathrm{pH}$ ). Minerotrophic sites received ground water and nutrient inputs from the surrounding catchment whereas the ombrotrophic site was "fed" by precipitation and dry deposition only.

Each site (see abbreviations in Table 1) included a pristine control plot (P), a plot with short-term water-level drawdown (STD), and a plot with long-term water-level drawdown (LTD), all of which had uniform vegetation and soil properties before disturbance. The P and STD plots at the OM site included dry hummock (Hu), intermediate lawn (La) and wet hollow (Ho) microforms. The LTD plots were drained by ditching for forestry in 1961 and the STD plots were ditch drained in 2000/2001 to simulate a predicted effect of climate change (Laine et al., 2004). The average water-level drawdown induced in the STD plots was about $10 \mathrm{~cm}$ during the growing season of 2003 in all sites, which is close to the estimate for the impact of climate change on water levels in northern peatlands (Roulet et al., 1992). In the LTD plots, the average water levels were about 15 (bog)-30 (fen) $\mathrm{cm}$ deeper than in the corresponding pristine sites. Together, these plots formed a successional gradient from a wet pristine peatland towards a dry peatland forest (Laiho et al., 2003). Water levels at the time of sampling are given in Table 1. The upper limit of the anaerobic layer is usually 5-15 cm closer to the surface than water level (Lähde, 1969, 1971).

The vegetation in the pristine ME site was characterized by sedges (Carex rostrata Stokes, C. lasiocarpa Ehrh.), some herbaceous species (e.g., Potentilla palustris Scop. and Menyanthes trifoliata L.) and mosses (e.g., Sphagnum fallax (Klinggr.) Klinggr., S. flexuosum Dozy \& Molk., S. magellanicum Brid.). The OL site was characterized by $C$. lasiocarpa, some Betula nana L., and S. papillosum Lindb., S. fallax, and S. flexuosum in the moss layer. In the OM site, Eriophorum vaginatum L., Andromeda polifolia L. and Rubus chamaemorus L. were the most abundant field layer species, while $S$. cuspidatum Hoffm. was the dominant moss in the Ho, S. balticum (Russow) C. Jens. in the La and $S$. fuscum (Schimp.) Klinggr. in the Hu microforms. Some stunted Scots pine (Pinus sylvestris L.) occurred on the hummocks. In the STD plots of the ME and OL sites, sedges had suffered while shrubs had flourished together with Scots pine and birch (Betula pubescens Ehrh.). The Sphagnum carpets showed signs of increased desiccation but had not decreased in cover. In the OM site, the changes in vegetation were small: most obviously, $S$. cuspidatum had decreased in cover and vitality. On the LTD plots, vegetation had changed dramatically. Tree stands had become tall and dense, and consisted of Scots pine in the OM site, and Scots pine with a mixture of birch and spruce (Picea abies (L.) Karst.) in the ME and OL sites. Shrubs characterized the field layer in all sites, being most notable at the OM site. Moss layers consisted of Pleurozium schreberi Brid., S. angustifolium (Russow) C. Jens., S. russowii Warnst. and S. magellanicum, with some S. fuscum on the OM LTD plot. In the OL and especially in the ME LTD plots, there were also surfaces covered mostly with birch leaf litter (i.e., no mosses).

Triplicate peat cores $(8 \times 8 \mathrm{~cm} ; \mathrm{n}=39)$ were taken at each plot and sub-sampled by depth: 0-5 (L1), 5-10 (L2), and 20-30 (L4) cm. All samples $(\mathrm{n}=117)$ were fresh frozen and stored at $-20{ }^{\circ} \mathrm{C}$ prior to molecular analysis. 


\subsection{DNA extraction, PCR-DGGE fingerprinting and phylogenetic analyses}

For peat soil DNA extraction, a modified manufacturer's protocol of the FastPrepTM DNA-kit (Bio101, Vista, CA, USA) and the bead-beating method of Yeates and Gillings (1998) was used as previously described (Jaatinen et al., 2004). We used the oligonucleotide primer set FF390 (with GC-clamp) and FR1 for fungi, which is reported to be suitable for analysing complex fungal communities from various environmental samples in DGGE (Vainio and Hantula, 2000; Pennanen et al., 2001). For the actinobacteria we used the primer set S-C-Act-235-a-S-20 (with GC-clamp) and S-C-Act-878-a-A-19, which amplifies DNA from various pure culture taxa and environmental samples (Stach et al., 2003). The primer set was optimized for DGGE-fingerprinting as in Jaatinen et al. (2008) and PCR amplifications with both primer sets were conducted as previously described (Stach et al., 2003; Jaatinen et al., 2008).

Microbial communities were analysed by DGGE using DCodeTMSystem (Bio-Rad, Hercules, CA, USA) with primer-specific denaturing gradients and running parameters (Vainio and Hantula, 2000; Jaatinen et al., 2008). Control ladders with several known DGGE bands of known mobility in the denaturing gradient gel were included for comparison in the sample runs. The DGGE gel photographs were screened for the presence (1) or absence (0) of fungal and actinobacterial bands using the AlphaImager 2.1 program of the AlphaDigiDoc gel documentation system (Alpha Innotech Corp., California, USA). To verify the presence or absence of a weak DGGE band and to control for possible fusion of closely migrating bands, DGGE gels were run at least twice. DGGE runs were optimized for band isolation and gels were poured on GelBond PAG film (FMC Bioproducts, Rockland, ME, USA) to minimize distortion. DGGE bands representing a unique sequence type (different mobility in DGGE) were selected for sequencing and excised, amplified and run again in DGGE three to five times so that we could be sure about their high quality and the right initial position in a gel. Finally, the sequences were reamplified with 20 or 25 cycles and purified with the QIAquick PCR purification kit (Qiagen GmbH, Hilden, Germany). Fungal PCR products were directly sequenced using a Long Readir 4200DNA Sequencer (LI-COR, Lincoln, Nebr., USA) with the SequiThermEXCEL ${ }^{\mathrm{TM}}$ II DNA Sequencing Kit-LC (Epicentre Technologies, Madison, WIS, USA) using infrared dyed primers FR1 and FF390 according to the manufacturer's protocol. Direct sequencing of the partial actinobacterial PCR products was conducted in both directions in a CEQTM8000 capillary electrophoresis device (Beckman Coulter, Fullerton, CA, USA) with the CEQ Dye Terminator Cycle Sequencing kit according to a modified manufacturer's protocol as previously reported (Jaatinen et al., 2008).

Thirty-one fungal and twenty-four actinobacterial DGGE-derived sequences were aligned with those available on the public databases of GenBank/EMBL/DDBJ and RDPII release 9.44 (Cole et al., 2005) using FastAligner 3.1 in the ARB software package (Ludwig et al., 2004). True chimeric (CHIMERA_CHECK version 2.7 in RDPII) and clearly non-fungal or non-actinobacterial sequences were excluded. Phylogenetic analyses were conducted as previously reported (Jaatinen et al., 2008). All sequence data obtained in this study has been deposited in the GenBank, EMBL and DDBJ databases under Accession Numbers EU527020 to EU527074.

\subsection{Community analyses}

First, we examined the extent of variation in the binary data of the observed seventyeight fungal and sixty actinobacterial DGGE bands with detrended correspondence analysis (DCA). According to the gradient lengths obtained using DCA, we applied a unimodal 
species response model for both the fungal 18SrDNA and the actinobacterial 16SrDNA derived binary data using correspondence analysis (CA) to detect patterns of variation in the banding patterns, and canonical correspondence analysis (CCA) for evaluating the significance of our explanatory variables (Lepš and Šmilauer, 2003). Rare species were downweighted in analyses. We used Canoco for Windows 4.5 software (ter Braak and Šmilauer, 2002).

We tested whether community structure differed between pristine sites with different nutrient levels (OM, OL, ME) using the binary matrix of DGGE-derived fungal or actinobacterial data as response variables, and binary variables describing the nutrient levels as explanatory variables. A significant canonical axis based on the environmental variables indicates differences in banding patterns among nutrient levels. Significance levels of the canonical axes were determined with Monte Carlo permutation tests. We tested each nutrient level separately for significant community structure changes following water-level drawdown using hydrological status (P, STD, LTD) as explanatory variables. Since we assumed that community structure would vary with depth in the peat profile, we separated this effect by using dummy variables indicating sampling depth as covariates in CCA. Similarly, we tested the effect of depth while using either nutrient level or hydrological status as covariates. We further analyzed the combined effects of depth and nutrient level, as well as depth and hydrological status (within nutrient level). We did this by constructing interaction terms showing both which layer and which site or hydrological status the samples represented, and using them as explanatory variables. The effect of microtopography (Hu, La, Ho) at the OM site was tested by using both sample depth and hydrological status (P vs. STD) as covariates.

Shannon-Weaver diversity indices (Shannon and Weaver, 1963) were calculated for each peat core (i.e., integrating layers L1-L3 per sampling location) as follows:

$$
H^{\prime}=-\sum_{i=1}^{\mathrm{s}} p i \ln (p i)
$$

where $p i$ is the proportion of each DNA band from all observed DGGE bands in a sample core and $\mathrm{S}$ the total number of DNA bands in the sample core. The index takes into account both the total number of the DGGE bands and the proportion of each band in the total of each peat core. The diversity indices were subjected to a two-way analysis of variance (ANOVA) with nutrient level and hydrological status as the main effects. Differences between the microforms in the OM P and STD plots were tested with a twoway ANOVA using microform and drainage status as the main effects. Tukey's test ( $p<$ 0.05 ) was used for pairwise comparisons. ANOVAs were completed using General Linear Models in the SYSTAT v. 10 package, which can handle unbalanced data; because of the microtopographical variation, we had more observations for OM than for the other sites.

\section{Results}

\subsection{Fungal and actinobacterial sequences}

We obtained representatives of four fungal phyla (Fig. 1). The majority of the sequences were split equally between Ascomycota (32\%) and Basidiomycota (32\%). The rest of the sequences belonged to two families (Monoblepharidaceae and Chytridiaceae) of the phylum Chytridiomycota (16\%), phylum Zygomycota (6\%), and to several 
uncultured fungal or eukaryotic sequences/clones (13\%) distantly related to any known fungus (Fig. 1). Almost all basidiomycete-related sequences clustered within the six different orders of the class Agaricomycetes, which contains $53 \%$ of described basidiomycetes. Ascomycete-related sequences clustered within four different classes of the subphylum Pezizomycotina, and within the order Saccharomycetales.

Over $80 \%$ of the actinobacterial DGGE sequences were most similar to uncultured actinobacterium/bacterium clones. All of the sequences were similar to actinobacterial sequences rather than some other group of bacteria, and clustered into two main clades (Fig. 2). Within these two clades, nine subclades of uncultured actinobacterium/bacterium clones were found as well as sequences most similar to Acidothermus cellulolyticus Mohagheghi, several Rhodococcus or Nocardia (family Nocardiaceae) strains, and several Mycobacterium strains.

\subsection{Fungal and actinobacterial communities in pristine sites}

Two gradients were distinguished in both the fungal and the actinobacterial community structure according to the CA (Figs. 3 and 4). The first axis corresponds in both cases to the variation in site nutrient level. Also, $\mathrm{pH}$ correlated with the main gradient of distribution for the fungal community. The left-hand side of the ordination plots represents the fen sites (ME and OL) while the right-hand side represents the bog site (OM) with all its microforms (Hu, La, Ho). CCA results confirmed that nutrient levels significantly affected $(\mathrm{p}=0.002)$ both the fungal and the actinobacterial banding patterns. The second axis corresponds to the distance of the sampled layer from water level, or sample depth. In Figs. 3 and 4, the lower part of the ordination diagram represents relatively drier and the upper part relatively wetter sampling locations.

Fungal communities were most different between the mesotrophic fen and the bog. Despite the differences observed between fens and bogs, and between peat layers with different wetness and, possibly, substrate quality, most fungi and actinobacteria found in the pristine peatland seemed robust to the environmental variables we measured. The first two canonical axes explained only $9 \%$ and $7 \%$ of the variation in the fungal community, and $9 \%$ and $8 \%$ of the variation in the actinobacterial community, respectively.

Generally, fungal diversity was slightly higher than that of actinobacteria in all sites. Both the fungal and the actinobacterial diversity correlated positively with site nutrient level ( $\mathrm{p}=0.001$ and $\mathrm{p}=0.008$, respectively), being significantly higher in both the fen sites compared to the bog (Table 2). Among the different microforms of the OM site, the fungal diversity in the intermediate La-level was significantly lower than in either the drier $\mathrm{Hu}$ - or wetter Ho-surfaces. The actinobacterial diversity did not vary significantly between microforms.

Some fungal sequences seemed to associate with certain nutrient levels, e.g., rj1F-24, -39 and -3 in fens, and rj1F-D in bog, or layers, e.g., rj1F-9, -33 and -47 , while others seemed to be more "generalist" (Fig. 3b; Appendix). There was no clear pattern in the obtained actinobacterial sequences in the pristine sites. Although, one actinobacterial sequence (rj1A-A18) showed some preference for the pristine bog site.

\subsection{Fungal community following water-level drawdown}

Persistent water-level drawdown induced significant changes in the fungal community composition at all sites ( $\mathrm{p}$-values for canonical axes < 0.05 ). Hydrological status alone explained from $7 \%(\mathrm{OM})$ to $13 \%(\mathrm{ME})$ of the variation in the fungal community, while sampling depth alone explained from 5\% (OM) to 10\% (OL). The responses to water- 
level drawdown were not uniform in all layers, but by accounting for both hydrological status and layer depth using the combined variables, $18 \%(\mathrm{OM})$ to $37 \%(\mathrm{OL})$ of the variation could be explained. Fungal communities in LTD plots of the different sites seemed to be more similar to each other than those in P plots (Fig. 5; LTD centroids are closer to each other than $\mathrm{P}$ centroids).

Fungal diversity responded significantly to hydrological status $(\mathrm{p}=0.018)$ and increased significantly following STD $(\mathrm{p}=0.013)$ (Table 2). Differences between P and LTD, and STD and LTD were not significant. In the OM site, the increasing trend generally continued after LTD but not strongly enough to make the site $\mathrm{x}$ hydrology interaction significant. Overall, there were slightly more fungal sequences that responded positively (appeared as new compared to P) than negatively (disappeared as compared to P) to STD (Table 3). In contrast, over half of the responses to LTD were negative, as compared to the pristine conditions. The CCA results implied that the responses to both STD and LTD were rather unidirectional in the ME and OM sites; however, in the OL site the community in the STD plot was even more different from that of the LTD plot than was the community of the P plot (Fig. 5).

Many fungal sequences were observed in all sites regardless of the hydrological condition or site, e.g., rj1F-Ftls, -Gtls, $-15,-28$, -C and -44 (Appendix). Our results indicate that basidiomycetes may be more sensitive (respond positively or negatively) to hydrological changes than ascomycetes (Table 3). Sequence rj1F-33 was the only ascomycete-related sequence that showed a response (positive) to LTD, even though the patterns were not consistent among sites. A sequence similar to genera Lactarius and Russula (rj1F-47) was observed only from the deepest 20-30 cm layer of the OM site after LTD, whereas it was observed from all layers of OL and from the top 0-10 cm layer of ME sites (Appendix). A sequence rj1F-o became observable after STD but was absent again after LTD. Differently, sequence rj1F-D was observed in all OM plots, but was absent from $\mathrm{P}$ plots in the fen sites (Appendix). Some sequences, e.g., rj1F-42 and rj1F39 , occurred after STD only in some specific sites and in the other sites they were present despite the hydrological change. Three of the five Chytridiomycota sequences showed different responses to water-level drawdown depending on nutrient level (Table 3, Appendix).

\subsection{Actinobacterial community following water-level drawdown}

The effect of water-level drawdown on the actinobacterial banding pattern diminished directly with site nutrient level. In the ME site, the relationship was significant and accounted for $15 \%$ of the variation in banding pattern. In the OL site, the effect was only barely significant and accounted for $10 \%$ of the variation. Finally, in the OM site, the effect of water-level drawdown on the actinobacterial community was not significant. Similar to the fungal community, the actinobacterial community seemed to be generally more homogeneous across sites in LTD plots (Fig. 5).

Sample depth had a significant effect at all sites and influenced the banding patterns somewhat more than water level in the more nutrient-poor OL $(13 \%)$ and OM $(8 \%)$ sites. In the ME site, sample depth and water-level drawdown were equally effective; however, when accounting for the variation in both factors, $20 \%(\mathrm{OM})$ to $46 \%(\mathrm{ME})$ of the variation in banding pattern could be explained, which reemphasizes the specific relationship between response and layer depth. Actinobacterial diversity did not respond significantly to hydrological status $(\mathrm{p}=0.461)$ (Table 2).

Sequences rj1A-A3, -B9, -B12, -A16, -B17 and -B26 were ubiquitous. In general, almost equal numbers of the obtained sequences responded positively and negatively to 
both STD and LTD (Table 4). Changes in detected sequences after water-level drawdown were mainly co-dependent on nutrient level. For example, sequences rj1A-A8, -B16, B15, and -B24 showed a negative response to LTD in the ME site only (Table 4). In contrast, sequences rj1A-A7 and B18 were observed in all sites except in OM following LTD. Sequence rj1A-B3 was common in the OL sites and sporadically observed in the ME site following water-level drawdown, and in all hydrological conditions in the OM site.

\section{Discussion}

\subsection{Fungal and actinobacterial sequences}

The fungal primers generated a PCR-product of $390 \mathrm{bp}$ and provided relatively high resolution in DGGE for the various fungal taxa, similar to the performance noted by Vainio and Hantula (2000). Since only $32 \%$ of the obtained sequences showed any similarity to ascomycetes, our results do not support the implication based on cultivation and isolation methods that ascomycetes represent over $80 \%$ of the fungal species found in peatlands (Thormann et al., 2006b). Both methods have their flaws: the cultivation methods may favor fast-growing species that produce large numbers of spores (Artz et al., 2007) whereas the molecular PCR-DGGE based methods may overestimate species that are present with high DNA concentrations in the samples. Problems with direct sequencing from DGGE arise also when bands are insufficiently resolved, which makes them difficult to separate by excision; this explains why only ca. $40 \%$ of our fungal DGGE bands were successfully sequenced.

Fungal sequences clustered with fungi capable of utilizing a broad range of substrates. Chytrids belonging to genera Rhizidium, Chytriomyces and Podochytrium are known to mineralize chitin (Kiziewicz and Kurzatkowska, 2004). Zygomycetes (genus Mortierella) are pioneer saprobes that remain common throughout the entire process of decomposition (Deacon, 1997; Thormann, 2006b). Several mitosporic ascomycetes cover aquatic polysaccharide degraders (e.g., Tethachaetum, Articulospora) (Chamier and Dixon, 1982), aero-aquatic cellulose degraders (e.g, Helicodendron, Helicoon) (Fisher et al., 1977; Abdullah and Taj-Aldeen, 1989), woody-litter degraders (Lulworthia) (Bucher et al., 2004). Basidiomycetes-related sequences showed similarity to genera containing ectomycorrhizal (ECM) fungi (e.g., Clavaria, Russula, Lactarius), wood-decomposers (Cymatoderma and Panus) and cellulose-litter decomposers (Mycena and Baeosphora) (Lindahl and Boberg, 2008). Sequences related to phylum Glomeromycota, arbuscularmycorrhizal (AM) fungi were not obtained although they form mutualistic associations with fen plants such as sedges (Turner et al., 2000); however, they are probably more common in more nutrient-rich fens (Wolfe et al., 2007).

That most of the obtained actinobacterial sequences did not match any actinobacterial sequences probably reflects an incomplete coverage currently available in public databases. A minority of sequences were similar to members of Rhodococcus, Nocardia and Mycobacterium, which are commonly found in soil and water and include human pathogens, saprophytes (Ryan, 2004) and decomposers able to process complex aromatics (van der Geize and Dijkhuizen, 2004), lignin (Trojanowski et al., 1977; Haider et al., 1978) and complex hydrocarbons such as petroleum distillates (Aislabie et al., 1998). 


\subsection{Fungal and actinobacterial communities in pristine sites}

The result that fungal and actinobacterial communities separated between the two fen sites and the bog site is in line with the vegetation pattern which is more similar between the two fens than between either of the fens and the bog. This reflects ecohydrological and, consequently, physical and chemical characteristics (e.g., $\mathrm{pH}$, substrate quality, gas exchange) of the peatland types (Table 1; Laine et al., 2004; Jaatinen et al., 2007). It seems that fungi in the pristine sites are more affected by moisture or aeration (Lähde, 1969) of the substrate, measured as distance to water level, while actinobacteria respond more to some other depth-related factor, possibly substrate quality, which generally decreases downwards along with the more advanced state of decomposition (Hogg et al., 1992; Hogg; 1993). Microbial diversities were higher in the fens than in the bog, which is a pattern similar to that found for plant species diversity (Laine et al., 1995). This pattern may reflect the variation in substrate quality and heterogeneity: saprobes differ in their ability to utilize different compounds as $C$ sources (Thormann et al., 2001, 2002) and may affiliate with different litter types according to their chemical composition (Thormann, 2004). Plant community composition also has implications for fungal mycorrhizal associations (Natel and Neumann, 1992).

The result that fungal communities were most different between the mesotrophic fen and bog is congruent with the results from Swedish mires (Nilsson et al., 1992) and a Scottish moorland-forest gradient (Anderson et al., 2003), where the site type seemed to be the strongest determinant of fungal community. Despite the detected differences between fens and bogs, we want to emphasize that most of the fungal and actinobacterial sequences found in the pristine peatland were not highly affected by the environmental variables. Thus, it seems that most fungi and actinobacteria in boreal peatlands may be rather resilient to variation in environmental conditions. On the other hand, we must bear in mind that molecular techniques such as DGGE and sequencing are qualitative approaches that reveal only the presence of certain taxa and provide no information on their relative activity rates under the different conditions.

Some sequences were characteristic of fen sites. For example, sequences rj1F-24 and 39 , which clustered with novel uncultured fungal sequences, could represent a species characteristic of wet, nutrient-rich mesotrophic fens. In addition, sequence rj1F-3 was most similar to uncultured sequences of Mortierellaceae (mainly soil saprobes; White et al., 2006) and characterized the 5-10 cm layer of the oligotrophic fen.

In contrast, some of the obtained sequences apparently represent species characterizing the nutrient-poor environment of the bog site, e.g., Helicoon- and Tyrannosorusrelated sequence (rj1F-D) seemed typical of the upper layers of the bog site. These fungi include major decomposers of wood and plant litter as well as plant parasites and biotrophs (Goos, 1987). Helicoon fuscosporum is known to degrade cellulose (Fisher et al., 1977). Interestingly, two species of Helicoon ( $H$. myosuroides Voglmayr and $H$. dendroides Voglmayr) have also earlier been suggested to be specialists of raised bogs (Voglmayr, 1997).

Even though the abundance and growth of some mycorrhizae may be limited in soil that is either flooded or too dry (Lodge, 1989), woody plants in wet peatland habitats are commonly mycorrhizal (Glenn et al., 1991; Thormann et al., 1999; Baar et al., 2002). Ericoid (ERM), AM and ECM fungi have been observed in different shrub and tree species from peatlands (Thormann et al., 1999). In our study, ECM fungi related sequence, rj1F-47, was found from the top layers in all our pristine sites, except the wettest hollow surface of the bog site. 
Only one actinobacterial sequence showed some preference for the pristine bog site. This sequence was similar to uncultured group of actinobacterium or bacterium sequences, which are only distantly related to the known actinobacterial taxa and thus might represent a novel lineage.

\subsection{Fungal community following water-level drawdown}

Our results indicate that the fungal community responds to persistent water-level drawdown, especially in fens. Also the sampling depth seems to have a strong effect on the community and its response. These results agree with our earlier observations from the northern boreal fen Suonukkasuo (Jaatinen et al., 2008), and emphasize the interactive roles of water level, site type and depth in shaping the fungal communities. The fungal communities after long-term water-level drawdown become more similar among sites with different nutrient levels than those of the pristine plots, resembling the changes in vegetation pattern. Earlier, Trinder et al. (2008) have suggested that litter type may have a greater impact than water level on peatland fungal communities.

Short-term drainage affects many fungal sequences positively rather than negatively and the effect is opposite after long-term drainage, which calls for some attention. In wet conditions, where oxygen concentration drops rapidly when moving from the peat surface downwards (Boggie, 1977), it is likely that specialist species dominate the microbial community. For each nutrient level, the environmental conditions are further modified by the quality of soil water. Following short-term water-level drawdown, changes in environmental conditions, including litter quality, moisture, $\mathrm{pH}$, temperature and oxygen availability, are still rather small (Jaatinen et al., 2007; Vávřová et al., unpublished), but seemingly enough to allow colonization by more common aerobes. This will first lead to an overlap of communities, and higher overall diversity. Following long-term water-level drawdown, upon establishment of the drier conditions, the environment dramatically differs from the pristine one (Laiho, 2006). Continued gradual replacement of specialists by generalists leads to lowered diversity. Similar patterns of turnover have been observed for vegetation (Laine et al., 1995; Vasander et al., 1997). Short-term here means 3-4 years, during which time the ecosystems we studied were still clearly under transient conditions. Based on vegetation studies, it may take several decades before the ecosystems have reached a new "equilibrium" state relative to the new hydrological conditions (Laine et al., 1995).

Our results suggest that hydrological changes, directly or indirectly via the change in vegetation and litter quality, may have a greater effect on the existence of basidiomycetes than ascomycetes. Only one of the obtained ascomycetes-related fungal sequences showed a response (positive) to long-term water-level drawdown. This sequence related to the Sordariales, which is a diverse group containing lignicolous, herbicolous, coprophilous and soil-dwelling taxa (Huhndorf et al., 2004).

We hesitate to say whether the differences observed in the response patterns among sites imply real differences in all cases, or simply reflect the limited coverage of our sample cores. For instance, Russulaceae are a common fungal group following the drainage of a boreal bog (Salo, 1980). Yet, in our data, a sequence similar to Russula and Lactarius was observed only from the deepest layer of the bog site after long-term waterlevel drawdown whereas it was observed from all layers of the oligotrophic fen site and from the top layer of the mesotrophic fen site. On the other hand, different Russulaceaespecies may be affected differently depending on the species; one Russula-related sequence strongly characterized the driest sampling location and another one the wetter location of the hydrological gradient in a boreal Suonukkasuo fen (Jaatinen et al., 2008). 
Notably, some species of Lactarius are known to have saprotrophic capabilities and may adopt the decomposing role depending on the ecological niche they live in (Buée et al., 2007).

A sequence related to Clavulina appeared after the transient conditions created by STD but disappeared when the drying succession continued. Species of Clavulina have been tentatively considered mycorrhizal, but a radiocarbon study demonstrated that some species of this genus are also saprobic (Hobbie et al., 2002). In addition, water-level drawdown may not affect at all, or affect positively some sequences representing basidiomycetes: e.g., a sequence belonging to the wood-decomposing genera Cymatoderma and Panus in the OL fen site and in the hummock-surfaces of the OM sites.

Chytridiomycota (or chytrids) seem to respond differently to water-level drawdown depending on the nutrient level. Chytrids thrive in aquatic environments and are found commonly in terrestrial habitats where a periodic film of surface water is available for dissemination of zoospores (Shearer et al., 2007). Many chytrids can survive periods of desiccation by the formation of resistant spores (Shearer et al., 2007). Thus, at least some of the obtained chytrid sequences might survive the moderate water-level drawdown but die when conditions become too dry for too long.

Overall, our results confirm the findings of a previous PLFA study and show that the fungal community response to changes in hydrology is dependent on the type of peatland (Jaatinen et al., 2007).

\subsection{Actinobacterial community following water-level drawdown}

Effect of water-level drawdown on actinobacteria only seemed apparent in the most nutrient-rich fen site and diminished as sites became more nutrient poor. Also, similar to fungi, the actinobacterial community seems to become more similar across sites after LTD. Sample depth seems to be a more important determinant of community structure at all sites and more influential than water level in the more nutrient-poor fen and bog sites. The results echo a trend observed in a northern boreal fen (Suonukkasuo) where the actinobacterial community response was more dependent on depth than water level and in contrast to the response of the fungal community (Jaatinen et al., 2008).

Several sequences might relate to generalist species, since they were observed throughout the peatland sites regardless of depth, nutrient level and hydrological conditions. These sequences were similar to Mycobacterium avium subsp. avium Chester, uncultured bacterium clones and Acidothermus cellulolyticus Mohagheghi. A sequence similar to rj1A-B17 was also found also in the Suonukkasuo fen but not at the wettest location of the hydrological gradient (Jaatinen et al., 2008).

Our results would indicate that the occurrence of some actinobacteria after water-level drawdown, either short- or long-term, is codependent on nutrient level. For example, LTD seems to negatively affect sequence rj1A-A8 (related to cellulolytic and xylanolytic Cellulolomonas species: e.g., Elberson et al., 2000; Rivas, 2004) only in the nutrient-rich fen. In contrast, LTD seems to negatively affect sequences rj1A-A7 and -B18 only in the bog. Thus, another Mycobacterium-related sequence may represent a species for which drying created a positive effect only in a certain type of peatland.

Some of our results showed a similar trend to the PLFA study from the same site indicating that at least some actinobacteria would have negative effects after water-level drawdown in the ME fen but positive in the OM bog (Jaatinen et al., 2008). Most of the actinobacterial DGGE sequences (over 70\%) were similar to unknown actinobacterial or bacterial sequences deriving from various different environments and showed a random distribution among hydrologically different sites. Their roles remain unclear. 


\subsection{Conclusions}

Our study obtained molecular data of fungi and actinobacteria from a complex peatland ecosystem with three site types differing in their vegetation (nutrient levels) and wetness. Our pristine plots formed an ecohydrological gradient from a wet, nutrient-rich mesotrophic fen to a nutrient-poor bog. The drained plots represented different stages of a secondary succession leading to more forest-like ecosystems. We detected sequences related to various fungal decomposers capable of using a broad range of substrates. Fens had more diverse fungal and actinobacterial communities compared to bogs. Fungal diversity increased following STD irrespective of site nutrient level. Furthermore, waterlevel drawdown also was associated with a change in the fungal sequences detected. In contrast, sampling depth seemed to have a greater effect on the actinobacterial communities, especially in nutrient-poor sites. However, changes in communities were neither drastic nor clear and it appears that the distribution of most sequences could be random and independent of the prevailing environmental conditions and this result reflects the dominance of generalists capable of utilizing various substrates.

Basidiomycetes seemed to be more responsive to water-level drawdown than ascomycetes. The response of each putative fungus was often different after short- and longterm water-level drawdown and/or dependent on peatland type. Overall, different fungi may have different strategies to cope with hydrological changes caused by climate change or forestry drainage and these strategies are at least partly dependent on peatland type. Actinobacteria in general were less sensitive to hydrological changes, although the response of some actinobacteria to water-level drawdown may similarly depend on peatland type. Generally, the differences between peatland types in both fungal and actinobacterial communities diminished after long-term water-level drawdown. This result is most likely connected to vegetation, which has become more similar (dominated by Scots pine) over the four decades.

The water-level drawdown in our sites was achieved by ditching and was thus faster than would likely happen with a gradual change in climate. While we assume that the general change patterns in the ecosystem structure would be similar, the timescale of change could be different according to a more gradual drying.

Our study has broadened the picture of fungal and actinobacterial community structure in natural and manipulated boreal peatland sites. To study the system further, a comprehensive clone library from the collection of peat soils should be completed. Also, using RNA as a molecular marker could open a window into the relative activity levels of different microbial species in the peatland community.

\section{Acknowledgements}

We thank Hannu Rantanen, Mirva Sandberg and Petra Vávřová for sampling with us, Mirva, Pablo Alvira Iraizoz, Piia Kinnunen, and Sirpa Tiikkainen for excellent technical assistance with sample preparations and molecular laboratory analyses, Oili Kiikkilä for the help with the statistics and Michael Hardman for the language check. This work was financially supported by the Academy of Finland (104425, 124573). 


\section{References}

Abdullah, S.K., Taj-Aldeen, S.J. 1989. Extracellular enzymatic activity of aquatic and aero-aquatic conidial fungi. Hydrobiologia 174, 217-223.

Aislabie, J., McLeod, M., Fraser, R., 1998. Potential for biodegradation of hydrocarbons in soil from the Ross Dependency, Antarctica. Applied Microbiology \& Biotechnology 49, 210-214.

Anderson, I.C., Campbell, C.D., Prosser, J.I., 2003. Diversity of fungi in organic soils under a moorland - Scots pine (Pinus sylvestris L.) gradient. Environmental Microbiology 5, 1121-1132.

Artz, R., Anderson, I.C., Chapman, S.J., Hagn, A., Schloter, M., Potts, J.M., Campbell, C.D., 2007. Changes in fungal community composition in response to vegetational succession during the natural regeneration of cutover peatlands. Microbial Ecology 54, 508-522.

Baar, J., Bastiaans, T., van de Coevering, M.A., Roelofs, J.G.M., 2002. Ectomycorrhizal root development in wet Alder carr forests in response to desiccation and eutrophication. Mycorrhiza 12, 147-151.

Basiliko, N, Yavitt, J.B, Dees, P.M, Merkel, S.M., 2003. Methane biogeochemistry and methanogen communities in two northern peatland ecosystems, New York State. Geomicrobiology Journal 20, 563-577.

Boggie, R., 1977. Water-table depth and oxygen content of deep peat in relation to root growth of Pinus contorta. Plant \& Soil 48, 447-454.

Bucher, V.V.C., Hyde, K.D., Pointing, S.B. and Reddy, C.A. (2004). Production of wood decay enzymes, mass loss and lignin solubilization in wood by marine ascomycetes and their anamorphs. Fungal Diversity 15, 1-14.

Buée, M., Courty, P.E., Mignot, D., Garbaye, J., 2007. Soil niche effect on species diversity and catabolic activities in an ectomycorrhizal fungal community. Soil Biology \& Biochemistry 39, 1947-1955.

Chamier, A.-C., Dixon, P.A., 1982. Pectinases in leaf degradation by aquatic hyphomycetes: the enzymes and leaf maceration. Journal of General Micorbiology 128, 2469-2483.

Cole, J.R., Chai, B., Farris, R.J., Wang, Q., Kulam, S.A., McGarrell, D.M., Garrity, G.M., Tiedje, J.M., 2005. The Ribosomal Database Project (RDP-II): sequences and tools for high-throughput rRNA analysis. Nucleic Acids Research 33 (Database Issue), D294-D296. doi:10.1093/nar/gki038

Deacon , J.W. 1997. Modern Mycology. 3rd edition. Blackwell, Boston.

Dedysh, S.N, Pankratov, T.A., Belova, S.E., Kulichevskaya, I.S., Liesack, W., 2006. Phylogenetic analysis and In Situ identification of Bacteria community composition in an acidic Sphagnum peat bog. Applied \& Environmental Microbiology 72, 2110 2117.

Dedysh, S.N., Panikov, N.S., Liesack, W., Großkopf, R., Zhou, J., Tiedje, J.M., 1998. Isolation of acidophilic methane-oxidizing bacteria from northern peat wetlands. Science 282, 281-284.

Elberson, M.A., Malekzadeh, F., Yazdi, M.T., Kameranpour, N., Noori-Daloii, M.R., Matte, M.H., Shahamat, M., Colwell, R.R., Sowers, K.R., 2000. Cellulomonas persica sp. nov. and Cellulomonas iranensis sp. nov., mesophilic cellulose-degrading bacteria isolated from forest soils. International Journal of Systematic \& Evolutionary Microbiology 50, 993-996.

Fisher, J.P., Sharma, P.D., Webster, J. 1977. Cellulolytic ability of aero-aquatic Hyphomycetes. Transactions of the British Mycological Society 69, 495-496. 
Galand, P., Saarnio, S., Fritze, H, Yrjälä, K., 2002. Depth related diversity of methanogen Archaea in Finnish oligotrophic fen. FEMS Microbiology Ecology 41, 441-449.

Glenn, M.G., Wagner, W.S., Webb, S.L., 1991. Mycorrhizal status of mature red spruce (Picea rubens Sarg.) in mesic and wetland sites of northwestern New Jersey. Canadian Journal of Forest Research 21, 741-749.

Goodfellow, M., Williams, S.T., 1983. Ecology of actinomycetes. Annual Review of Microbiology 37, 189-216.

Goos, R.D., 1987. Fungi with a twist: the helicosporous hyphomycetes. Mycologia 79, 122.

Haider, K., Trojanowski, J., Sundman, V., 1978. Screening for lignin degrading bacteria by means of ${ }^{14} \mathrm{C}$-labelled lignins. Archives of Microbiology 119, 103-106.

Hobbie, E.A., Weber, N.S., Trappe, J.M., van Klinken, G., 2002. Using radiocarbon to determine the mycorrhizal status of fungi. New Phytologist 156, 129-136.

Hogg, E.H., 1993. Decay potential of hummock and hollow Sphagnum peats at different depths in a Swedish raised bog. Oikos 66, 269-278.

Hogg, E.H., Lieffers, V.J., Wein, R.W., 1992. Potential carbon losses from peat profiles: effects of temperature, drought cycles, and fire. Ecological Applications 2, 298-306.

Huhndorf, S.M., Miller, A.N., Fernández, F.A., 2004. Molecular systematics of the Sordariales: the order and the family Lasiosphaeriaceae redefined. Mycologia 96, 368-387.

Jaatinen, K., Laiho, R., Vuorenmaa, A., del Castillo, U., Minkkinen, K., Pennanen, T., Penttilä, T., Fritze, H., 2008. Responses of aerobic microbial communities and soil respiration to water-level drawdown in a northern boreal fen. Environmental Microbiology 10, 339-353.

Jaatinen, K., Fritze, H., Laine, J., Laiho, R., 2007. Effects of short- and long-term waterlevel drawdown on the populations and activity of aerobic decomposers in a boreal peatland. Global Change Biology 13, 491-510.

Jaatinen, K., Tuittila, E.-S., Laine, J., Yrjälä, K., Fritze, H., 2005. Methane-oxidizing bacteria (MOB) in a Finnish raised mire complex: effects of site fertility and drainage. Microbial Ecology 50, 429-439.

Jaatinen, K., Knief, C., Dunfield, P.F., Yrjälä, K., Fritze, H., 2004. Methanotrophic bacteria in boreal forest soil after fire. FEMS Microbiology Ecology 50, 195-202.

Kim, S.-Y., Lee, S.-H., Freeman, C., Fenner, N., Kang , H., 2008. Comparative analysis of soil microbial communities and their responses to the short-term drought in bog, fen, and riparian wetlands. Soil Biology \& Biochemistry 40, 2874-2880.

Kiziewicz, B., Kurzatkowska, A., 2004. Aquatic fungi and fungus-like organisms isolated from surface waters situated near Białystok in Podlasie Province of Poland using the insect Notonecta glauca as bait. Mycologia Balcanica 1, 117-123.

Kraigher, B., Stres, B., Hacin, J., Ausec, L., Mahne, I., van Elsas, J., Mandic-Mulec, I., 2006. Microbial activity and community structure in two drained fen soils in the Ljubljana Marsh. Soil Biology \& Biochemistry 38, 2762-2771.

Lähde, E., 1969. Biological activity in some natural and drained peat soils with special reference to oxidation-reduction conditions. Acta Forestalia Fennica 94, 1-69.

Lähde, E., 1971. Anaerobisten olosuhteiden ja aerobisuusrajan esiintymisestä erilaisilla luonnontilaisilla turvemailla ja merkityksestä suotyypin kuvaajana (Summary: On anaerobic conditions in various virgin peat soils and the significance of the aerobic limit as an indicator of site quality). Silva Fennica 5, 36-48.

Laiho, R., 2006. Decomposition in peatlands: reconciling seemingly contrasting results on the impacts of lowered water levels. Soil Biology \& Biochemistry 38, 2011-2024. 
Laiho, R., Vasander, H., Penttilä, T., Laine, J., 2003. Dynamics of plant mediated organic matter and nutrient cycling following water-level drawdown in boreal peatlands. Global Biogeochemical Cycles 17, 1053, doi:10.1029/2002GB002015.

Laine, J., Vasander, H., Laiho, R., 1995. Long-term effects of water level drawdown on the vegetation of drained pine mires in southern Finland. Journal of Applied Ecology $32,785-802$.

Laine, J., Komulainen, V.M., Laiho, R., Minkkinen, K., Rasinmäki, A., Sallantaus, T., Sarkkola, S., Silvan, N., Tolonen, K., Tuittila, E.-S., Vasander, H., Päivänen, J., 2004. Lakkasuo - a guide to mire ecosystem. University of Helsinki Department of Forest Ecology Publications 31, 123 pp.

Lepš, J., Šmilauer, P., 2003. Multivariate Analysis of Ecological Data Using CANOCO. Cambridge University Press, Cambridge, UK.

Lindahl, B., Boberg, J. 2008. Distribution and function of litter basidiomycetes in coniferous forest. In: Boddy, L., Frankland, J.C., van West, P. (Eds.), Ecology of Saprotrophic Basidiomycetes. British Mycological Society Symposia Series. Academic Press. pp.183-196.

Lodge, D.J., 1989. The influence of soil moisture and flooding on formation of VA-endoand ectomycorrhizae in Populus and Salix. Plant \& Soil 117, 243-253.

Ludwig, W, Strunk, O, Westram, R, Richter, L, Meier, H, Yadhukumar, Buchner, A, Lai, T, Steppi, S, Jobb, G, Förster, W, Brettske, I, Gerber, S, Ginhart, AW, Gross, O, Grumann, S,Hermann, S, Jost, R, König, A, Liss, T, Lüßmann, R, May, M, Nonhoff, B, Reichel, B, Strehlow, R, Stamatakis, A, Stuckmann, N,Vilbig, A, Lenke, M, Ludwig, T, Bode, Schleifer, K-H 2004. ARB: a software environment for sequence data. Nucleic Acids Research 32, 1363-1371.

McCarthy, A.J., 1987. Lignocellulose-degrading actinomycetes. FEMS Microbiology Reviews 46, 145-163.

Morales, S.E., Moluser, P.J., Ward, N., Hudman, S.P., Gotelli, N.J., Ross, D.S., Lewis, T.A. 2006. Comparison of bacterial communities in New England Sphagnum bogs using terminal restriction fragment length polymorphism (T-RFLP) Microbial Ecology 52, 34-44.

Morris, S.A., Radajewski, S., Willison, T.W., Murrell, J.C., 2002. Identification of the functionally active methanotroph population in a peat soil microcosm by stable-isotope probing. Applied \& Environmental Microbiology 68, 1446-1453.

Natel, P., Neumann, P., 1992. Ecology of ectomycorrhizal-basidiomycete communities on a local vegetation gradient. Ecology 73, 99-117.

Nilsson, M., Bååth, E., Söderström, B., 1992. The microfungal communities of a mixed mire in northern Sweden. Canadian Journal of Botany 70, 272-276.

Pankratov, T.A., Dedysh, S.N., Zavarzin, G.A., 2006. The leading role of actinobacteria in aerobic cellulose degradation in Sphagnum peat bogs. Doklady Biological Sciences 410, 428-430.

Pennanen, T., Paavolainen, L., Hantula, J., 2001. Rapid PCR-based method for the direct analysis of fungal communities in complex environmental samples. Soil Biology \& Biochemistry 33, 697-699.

Raghoebarsing, A.A., Smolders, A.J.P., Schmid, M.C., Rijpstra, W.I.C., Wolters-Arts, M., Derksen, J., Jetten, M.S.M.., Schouten, S., Sinninghe Damsté, J.S., Lamers, L.P.M., Roelofs, J.G.M.., Op den Camp, H.J.M.., Strous, M., 2005. Methanotrophic symbionts provide carbon for photosynthesis in peat bogs. Nature 436, 1153-1156.

Roulet, N., Moore, T., Bubier, J., Lafleur, P., 1992. Northern fens: methane flux and climatic change. Tellus 44B, 100-105. 
Rivas, R., Trujillo, M.E., Mateos, P.F., Martínez-Molina, E., Velázquez, E., 2004. Cellulomonas xylanilytica sp. nov., a cellulolytic and xylanolytic bacterium isolated from a decayed elm tree. International Journal of Systematic and Evolutionary Microbiology 54, 533-536.

Ryan, K.J., 2004. Part V: Pathogenic Bacteria. Chapter 29: Actinomyces and Nocardia.In: Ryan, K.J., Ray, C.G. (Eds.) Sherris Medical Microbiology, 4th Edition. McGraw Hill. pp. 457-462.

Salo, K., 1980. Luonnontilaisen rämeen ja rämemuuttumien sienilajisto. Suo 31, 67-71 (Finnish).

Shannon, C.E., Weaver, W., 1963. The mathematical theory of communication. Urbana, IL, University of Illinois Press.

Shearer, C.A., Descals, E., Kohlmeyer, B., Kohlmeyer, J., Marvanová, L., Padgett, D., Porter, D., Raja, H.A., Schmit, J.P., Thorton, H.A., Voglymayr, H., 2007. Fungal biodiversity in aquatic habitats. Biodiversity and Conservation 16, 49-67.

Sizova, M.V., Panikov, N.S., Tourova, T.P., Flanagan, P.W., 2003. Isolation and characterization of oligotrophic acido-tolerant methanogenic consortia from a Sphagnum peat bog. FEMS Microbiology Ecology 45, 301-315.

Stach, J.E.M., Maldonado, L.A., Ward, A.C., Goodfellow, M., Bull, A.T., 2003. New primers for the class Actinobacteria: application to marine and terrestrial environments. Environmental Microbiology 5, 828-841.

ter Braak, C.J.F., Šmilauer, P., 2002. CANOCO reference manual and CanoDraw for Windows user's guide: Software for canonical community ordination (version 4.5). Microcomputer Power, Ithaca.

Thormann, M.N., Currah, R.S., Bayley, S.E., 1999. The mycorrhizal status of the dominant vegetation along a peatland gradient in southern boreal Alberta, Canada. Wetlands 19, 438-450.

Thormann, M.N., Currah, R.S., Bayley, S.E., 2001. Microfungi isolated from Sphagnum fuscum from a southern boreal bog in Alberta, Canada. The Bryologist 104, 548-559.

Thormann, M.N., Currah, R.S., Bayley, S.E., 2002. The relative ability of fungi from Sphagnum fuscum to decompose selected carbon sources. Canadian Journal of Microbiology 48, 204-211.

Thormann, M.N., Currah, R.S., Bayley, S.E., 2004. Patterns of distribution of microfungi in decomposing bog and fen plants. Canadian Journal of Botany 82, 710-720.

Thormann, M.N., 2006a. Diversity and function of fungi in peatlands: a carbon cycling perspective. Canadian Journal of Microbiology 86, 281-293.

Thormann, M.N., 2006b. The role of fungi in boreal peatlands. In: Wieder, R.F., Vitt, D.H. (Eds.) Ecological Studies. Boreal Peatland Ecosystems. Vol. 88. Berlin, Germany, Springer-Verlag pp. 101-123.

Trinder, C.J., Artz, R.R.E, Johnson, D., 2008. Interactions between fungal community structure, litter decomposition and depth of water-table in a cutover peatland. FEMS Microbiology Ecology 64, 433-448.

Trojanowski, J., Haider, K., Sundman, V., 1977. Decomposition of ${ }^{14} \mathrm{C}$-labelled lignin and phenols by a Nocardia sp. Archives of Microbiology 114, 149-153.

Turner, S.D., Amon, J.P., Schneble, R.M., Friese, C.F., 2000. Mycorrhizal fungi associated with plants in ground-water fed wetlands. Wetlands 20, 200-204.

Vainio, E.J., Hantula, J., 2000. Direct analysis of wood-inhabiting fungi using denaturing gradient gel electrophoresis of amplified ribosomal DNA. Mycological Research 104, 927-936.

van der Geize, R., Dijkhuizen, L., 2004. Harnessing the catabolic diversity of rhodococci for environmental and biotechnological applications. Microbiology 7, 255-261. 
Vasander, H., Laiho, R., Laine, J., 1997. Changes in species diversity in peatlands drained for forestry. In: Trettin, C.C., Jurgensen, M.F., Grigal, D.F., Gale, M.R., Jeglum, J.K. (Eds.), Northern Forested Wetlands: Ecology and Management, CRC Press, Lewis Publishers, Boca Raton, Fla, USA. ISBN 1-56670-177-5, pp. 109-119.

White, M.M., James, T.Y., O'Donnell, K., Cafaro, M.J., Tanabe, Y., Sugiyama, J., 2006. Phylogeny of the Zygomycota based on nuclear ribosomal sequence data. Mycologia 98, 872-884.

Wolfe, D., Mummey, D.L., Rillig, M.C., Klironomos, J.N., 2007. Small-scale spatial heterogeneity of arbuscular mycorrhizal fungal abundace and community composition in a wetland plant community. Mycorrhiza 17, 175-183.

Voglmayr, H., 1997. Helicoon myosuroides sp. nov. and Helicoon dendroides sp. nov., two new aero-aquatic hyphomycetes. Mycological Research 101, 337-340.

Yeates, C., Gillings, M.R., 1998. Rapid purification of DNA from soil for molecular biodiversity analysis. Letters in Applied Microbiology 27, 49-53. 


\section{Tables}

Table 1. Average water-levels, peat element concentrations and $\mathrm{pH}(6 \mathrm{~mL}$ fresh peat in water; 1:3; vol:vol) with standard errors (SE) for each plot at the time of sampling (May 2004). Nitrogen concentration was measured with a LECO CHN-1000 analyzer, the other element concentrations with an ICP emission spectrometer after dry ashing.

\begin{tabular}{|c|c|c|c|c|c|c|c|}
\hline Plot & $\begin{array}{l}\text { WL } \\
(\mathrm{cm})\end{array}$ & Layer & $\mathrm{N}$ & $\mathrm{P}$ & $\mathrm{K}$ & $\mathrm{Ca}$ & $\mathrm{pH}$ \\
\hline \multirow[t]{3}{*}{ P ME } & 0 & L1 & $2.11(0.21)$ & $851(74)$ & $1021(190)$ & $5910(804)$ & $5.9(0.18)$ \\
\hline & & L2 & $2.38(0.02)$ & 814 (17) & 786 (64) & $6410(703)$ & $5.7(0.24)$ \\
\hline & & L4 & $2.61(0.15)$ & $558(43)$ & $96(2)$ & $6277(433)$ & $5.3(0.02)$ \\
\hline \multirow{3}{*}{ STD ME } & -15 & L1 & $2.08(0.15)$ & 933 (39) & 1015 (90) & 8317 (1230) & $5.4(0.22)$ \\
\hline & & L2 & $2.93(0.10)$ & $1110(68)$ & $620(71)$ & $5797(282)$ & $5.5(0.13)$ \\
\hline & & L4 & $2.40(0.03)$ & $553(23)$ & $89(14)$ & $6370(297)$ & $5.0(0.06)$ \\
\hline \multirow{3}{*}{ LTD ME } & -15 & L1 & $1.52(0.11)$ & 704 (68) & $851(208)$ & $3177(352)$ & $3.8(0.06)$ \\
\hline & & L2 & $2.04(0.34)$ & 766 (116) & $322(17)$ & 3247 (1012) & $3.8(0.13)$ \\
\hline & & L4 & $2.52(0.21)$ & $540(40)$ & $40(3)$ & $5127(767)$ & $4.5(0.01)$ \\
\hline \multirow[t]{3}{*}{ P OL } & -11 & L1 & $1.23(0.03)$ & $338(24)$ & 958 (139) & 5407 (122) & $4.6(0.05)$ \\
\hline & & L2 & $1.56(0.12)$ & 474 (36) & 314 (37) & $4423(405)$ & $4.6(0.08)$ \\
\hline & & L4 & $2.54(0.19)$ & $806(76)$ & $57(14)$ & $3813(128)$ & $4.8(0.01)$ \\
\hline \multirow[t]{3}{*}{ STD OL } & -30 & L1 & $1.36(0.12)$ & $401(32)$ & $1156(214)$ & 6830 (1203) & $4.9(0.30)$ \\
\hline & & L2 & $1.93(0.11)$ & $781(46)$ & $401(47)$ & 5237 (997) & $4.9(0.25)$ \\
\hline & & L4 & $2.54(0.05)$ & $806(14)$ & $50(10)$ & $3830(101)$ & $4.9(0.05)$ \\
\hline \multirow[t]{3}{*}{ LTD OL } & -30 & L1 & $2.21(0.20)$ & $1330(119)$ & 734 (196) & $3720(465)$ & $3.9(0.07)$ \\
\hline & & L2 & $2.97(0.04)$ & $1243(38)$ & $189(42)$ & $2473(238)$ & $4.2(0.12)$ \\
\hline & & L4 & $2.42(0.05)$ & 762 (19) & $30(0)$ & $3183(74)$ & $4.6(0.09)$ \\
\hline \multirow[t]{3}{*}{$\mathrm{P} \mathrm{OM} \mathrm{Hu}$} & -22 & L1 & $0.92(0.07)$ & $236(27)$ & 2017 (286) & $1500(32)$ & $4.0(0.09)$ \\
\hline & & L2 & $0.84(0.08)$ & $213(18)$ & $830(215)$ & $1327(41)$ & $3.8(0.03)$ \\
\hline & & L4 & $1.10(0.05)$ & $276(23)$ & $161(11)$ & $1263(43)$ & $3.6(0.03)$ \\
\hline \multirow[t]{3}{*}{ STD OM Hu } & -24 & L1 & $0.92(0.01)$ & $278(41)$ & 1305 (192) & 1593 (149) & $4.0(0.14)$ \\
\hline & & L2 & $0.96(0.01)$ & 248 (27) & 795 (59) & $1247(15)$ & $3.6(0.04)$ \\
\hline & & L4 & $1.18(0.03)$ & $280(28)$ & $222(27)$ & $1323(98)$ & $3.6(0.02)$ \\
\hline \multirow{3}{*}{ P OM La } & -6 & L1 & $0.87(0.03)$ & 170 (27) & $1917(406)$ & $1180(59)$ & $4.4(0.08)$ \\
\hline & & L2 & $0.93(0.11)$ & 200 (19) & $609(88)$ & $1203(58)$ & $3.9(0.08)$ \\
\hline & & L4 & $1.08(0.07)$ & $223(13)$ & $94(10)$ & $981(80)$ & $3.7(0.06)$ \\
\hline \multirow[t]{3}{*}{ STD OM La } & -15 & L1 & $1.09(0.13)$ & $286(35)$ & $1152(254)$ & $1180(49)$ & $3.8(0.09)$ \\
\hline & & L2 & $1.11(0.09)$ & $278(55)$ & $464(28)$ & $1233(110)$ & $3.7(0.01)$ \\
\hline & & L4 & $1.18(0.02)$ & 240 (19) & $101(25)$ & 998 (119) & $3.8(0.07)$ \\
\hline \multirow[t]{3}{*}{ P OM Ho } & -3 & L1 & $0.83(0.03)$ & $189(16)$ & 659 (318) & 798 (18) & $4.0(0.11)$ \\
\hline & & L2 & $1.05(0.06)$ & $190(28)$ & $205(68)$ & $731(8)$ & $4.0(0.04)$ \\
\hline & & L4 & $1.27(0.04)$ & $183(12)$ & $81(14)$ & $622(55)$ & $3.9(0.06)$ \\
\hline \multirow[t]{3}{*}{ STD OM Ho } & -10 & L1 & $1.09(0.12)$ & 297 (32) & $601(82)$ & $1023(9)$ & $4.0(0.04)$ \\
\hline & & L2 & $1.20(0.10)$ & 246 (49) & $216(64)$ & $825(10)$ & $4.1(0.06)$ \\
\hline & & L4 & $1.36(0.12)$ & $228(33)$ & $57(3)$ & 721 (129) & $3.9(0.12)$ \\
\hline \multirow[t]{3}{*}{ LTD OM } & -15 & L1 & $1.48(0.06)$ & $814(58)$ & $791(66)$ & $2923(156)$ & $3.7(0.15)$ \\
\hline & & L2 & $1.02(0.05)$ & $461(38)$ & $393(59)$ & $2197(202)$ & $3.6(0.02)$ \\
\hline & & L4 & $1.13(0.05)$ & $260(12)$ & $52(4)$ & $1147(208)$ & $3.6(0.01)$ \\
\hline
\end{tabular}

Abbreviations: P, pristine; STD, short-term drainage; LTD, long-term drainage, ME, mesotrophic; OL, oligotrophic; OM, ombrotrophic; Hu, hummock; La, Lawn; Ho, hollow. WL, water-level. L1, 0-5 cm; L2, 5-10 cm; L4, 20-30 cm. 
Table 2. Shannon-Weaver diversity indices $\left(H^{\prime}\right)$ for the fungal (Fung) and actinobacterial (Act) DGGE bands. Average of 3 sample cores per plot, standard error of mean in parentheses.

\begin{tabular}{|c|c|c|c|c|c|}
\hline & & & \multicolumn{3}{|c|}{ Hydrological status } \\
\hline & & & $\mathrm{P}$ & STD & LTD \\
\hline \multirow[t]{6}{*}{ Fung } & Nutrient level & $\mathrm{ME}$ & $3.56(0.09)$ & $3.75(0.07)$ & $3.51(0.07)$ \\
\hline & & OL & $3.28(0.11)$ & $3.68(0.15)$ & $3.49(0.14)$ \\
\hline & & OM & $3.12(0.08)$ & $3.27(0.08)$ & $3.42(0.07)$ \\
\hline & Microforms & $\mathrm{OM} \mathrm{Hu}$ & $3.12(0.04)$ & $3.34(0.03)$ & \\
\hline & & OM La & $2.90(0.08)$ & $3.21(0.06)$ & $3.42(0.07)$ \\
\hline & & OM Ho & $3.44(0.03)^{*}$ & $3.44(0.14)$ & \\
\hline \multirow[t]{6}{*}{ Act } & Nutrient level & $\mathrm{ME}$ & $3.18(0.08)$ & $2.82(0.38)$ & $2.83(0.15)$ \\
\hline & & OL & $3.16(0.07)$ & $3.31(0.09)$ & $3.44(0.09)$ \\
\hline & & $\mathrm{OM}$ & $2.70(0.09)$ & $2.95(0.07)$ & $3.19(0.09)$ \\
\hline & Microforms & $\mathrm{OM} \mathrm{Hu}$ & $2.82(0.16)$ & $3.11(0.13)$ & \\
\hline & & OM La & $2.68(0.23)$ & $2.93(0.13)$ & $3.19(0.09)$ \\
\hline & & OM Ho & $2.66(0.13)$ & $2.82(0.07)$ & \\
\hline
\end{tabular}

* One sample core from P OM Ho was excluded from the index-calculations because its value was an outlier. See footnote of Table 1 for abbreviations. 
Table 3. Fungal derived 18SrDNA sequences that showed either positive $(+)$ or negative (-) response to water-level drawdown.

\begin{tabular}{|c|c|c|c|c|c|c|c|}
\hline \multirow[b]{2}{*}{ Sequence } & \multirow[b]{2}{*}{ Taxonomic affiliation } & \multicolumn{2}{|c|}{$\mathrm{ME}$} & \multicolumn{2}{|c|}{$\mathrm{OL}$} & \multicolumn{2}{|c|}{$\mathrm{OM}$} \\
\hline & & STD & LTD & STD & LTD & STD & LTD \\
\hline rj1F-q & Rhizidium (C) & - & + & & - & - & - \\
\hline rj1F-9 & Chytriomyces (C) & & & & & + & \\
\hline rj1F-30 & Monoblepharella (C) & & & & - & + & \\
\hline rj1F-3 & uncultured fungus (Z) & + & - & & - & + & - \\
\hline rj1F-35 & uncultured fungus (Z) & - & + & & & + & \\
\hline rj1F-45 & Ascocalyx abietina (A) & & & & & $+/-$ & + \\
\hline rj1F-33 & Sordariales (A) & & - & & & & \\
\hline rj1F-47 & Lactarius/Russula (B) & & & & & - & + \\
\hline rj1F-o & Clavulina $(\mathrm{B})$ & & - & & & $+/-$ & - \\
\hline rj1F-D & Helicoon/Tyrannosorus (B) & + & - & + & & & \\
\hline rj1F-x & uncultured Boletaceae (B) & & - & & - & - & - \\
\hline rj1F-s & uncultured fungus (B) & & & & - & - & - \\
\hline rj1F-42 & Cymatoderma/Panus (B) & & & + & & + & \\
\hline rj1F-39 & uncultured Boletaceae (B) & & & & & + & \\
\hline rj1F-26 & Mycena/Baeospora $(\mathrm{B})$ & & & & & - & \\
\hline rj1F-50 & uncultured soil fungus (B) & + & & & - & $+/-$ & + \\
\hline rj1F-18 & uncultured fungus (novel) & & & & & + & \\
\hline rj1F-24 & uncultured fungus (novel) & & & + & - & & \\
\hline
\end{tabular}

Abbreviations: B, Basidiomycota; A, Ascomycota; Z, Zygomycota; C, Chytridiomycota; See footnote of Table 1 for abbreviations 
Table 4. Actinobacterial derived 16SrDNA sequences that showed either positive (+) or negative (-) response to water-level drawdown.

\begin{tabular}{|c|c|c|c|c|c|c|c|}
\hline \multirow[b]{2}{*}{ Sequence } & \multirow[b]{2}{*}{ Taxonomic affiliation } & \multicolumn{2}{|c|}{$\mathrm{ME}$} & \multicolumn{2}{|c|}{ OL } & \multicolumn{2}{|c|}{$\mathrm{OM}$} \\
\hline & & STD & LTD & STD & LTD & STD & LTD \\
\hline rj1A-B3 & Mycobacterium & + & & & & - & + \\
\hline rj1A-A2 & Mycobacterium & - & + & + & & + & \\
\hline rj1A-A 8 & uncultured Cellulomonas & & - & - & & + & \\
\hline rj1A-A7 & uncultured bacterium & + & & & & + & - \\
\hline rj1A-A21 & uncultured bacterium & - & + & & & + & \\
\hline rj1A-B18 & uncultured bacterium & - & + & - & + & + & - \\
\hline rj1A-A 18 & uncultured bacterium & & + & + & - & & - \\
\hline rj1A-B16 & uncultured bacterium & & - & & & + & \\
\hline rj1A-B15 & uncultured bacterium & & - & & & - & + \\
\hline rj1A-B24 & uncultured bacterium & & - & & & $+/-$ & + \\
\hline rj1A-A20 & uncultured bacterium & & & & & + & \\
\hline rj1A-A13 & uncultured bacterium & & & & & + & \\
\hline rj1A-B23 & uncultured bacterium & & & & & - & + \\
\hline rj1A-B25 & uncultured bacterium & & & - & + & & - \\
\hline
\end{tabular}

See abbreviations in Table 1. 


\section{Figure legends}

Fig. 1. ARB generated phylogenetic tree of fungal partial 18SrDNA sequences. Scale bar represents $10 \%$ dissimilarity.

Fig. 2. ARB generated phylogenetic tree of actinobacterial partial 16SrDNA sequences. Scale bar represents $10 \%$ dissimilarity.

Fig. 3. Correspondence analysis (CA) of the fungal partial DGGE-derived 18SrDNA bands from the three pristine plots with different nutrient levels. a. The relation of the environmental variables to the 18SrDNA banding patterns. Centroids are shown for dummy variables and arrows represent continuous variables. Nutrient levels: ME, mesotrophic; OL, oligotrophic; OM, ombrotrophic. Microforms: Hu, hummock; La, lawn; Ho, hollow. Sampled layers: $\mathrm{L} 1=0-5 \mathrm{~cm}, \mathrm{~L} 2=5-10 \mathrm{~cm}, \mathrm{~L} 4=20-30 \mathrm{~cm}$ from the peat surface. Depth, sampling depth (cm from the peat surface; increases downwards); WL, depth of the water level (cm from the mire surface) at the time of sampling; Dist to WL; distance from the sampled layers to the water level. b. DGGE-derived partial 18SrDNA bands responsible for the separation of the samples. Included in the plot are such bands of whose variation axes 1 and 2 explained at least $10 \%$.

Fig. 4. Correspondence analysis (CA) of the actinobacterial partial DGGE-derived 16SrDNA bands from the three pristine sites with different nutrient levels. a. The relation of the environmental variables to the 16SrDNA banding patterns. Centroids are shown for dummy variables and arrows represent continuous variables. b. DGGE-derived partial 16SrDNA bands responsible for the separation of the samples. Included in the plot are such bands of whose variation axes 1 and 2 explained at least $10 \%$. See abbreviations in the legend of Fig 3.

Fig. 5. Differences between the plots representing different nutrient levels and hydrological conditions based on a. CA of the fungal partial DGGE-derived 18SrDNA bands, b. CA of the actinobacterial partial DGGE-derived 16SrDNA bands. Dummy variables indicating the layers sampled were used as covariates. Nutrient levels: ME, mesotrophic; OL, oligotrophic; OM, ombrotrophic. Hydrological conditions: P, pristine; STD, short-term drainage; LTD, long-term drainage. 


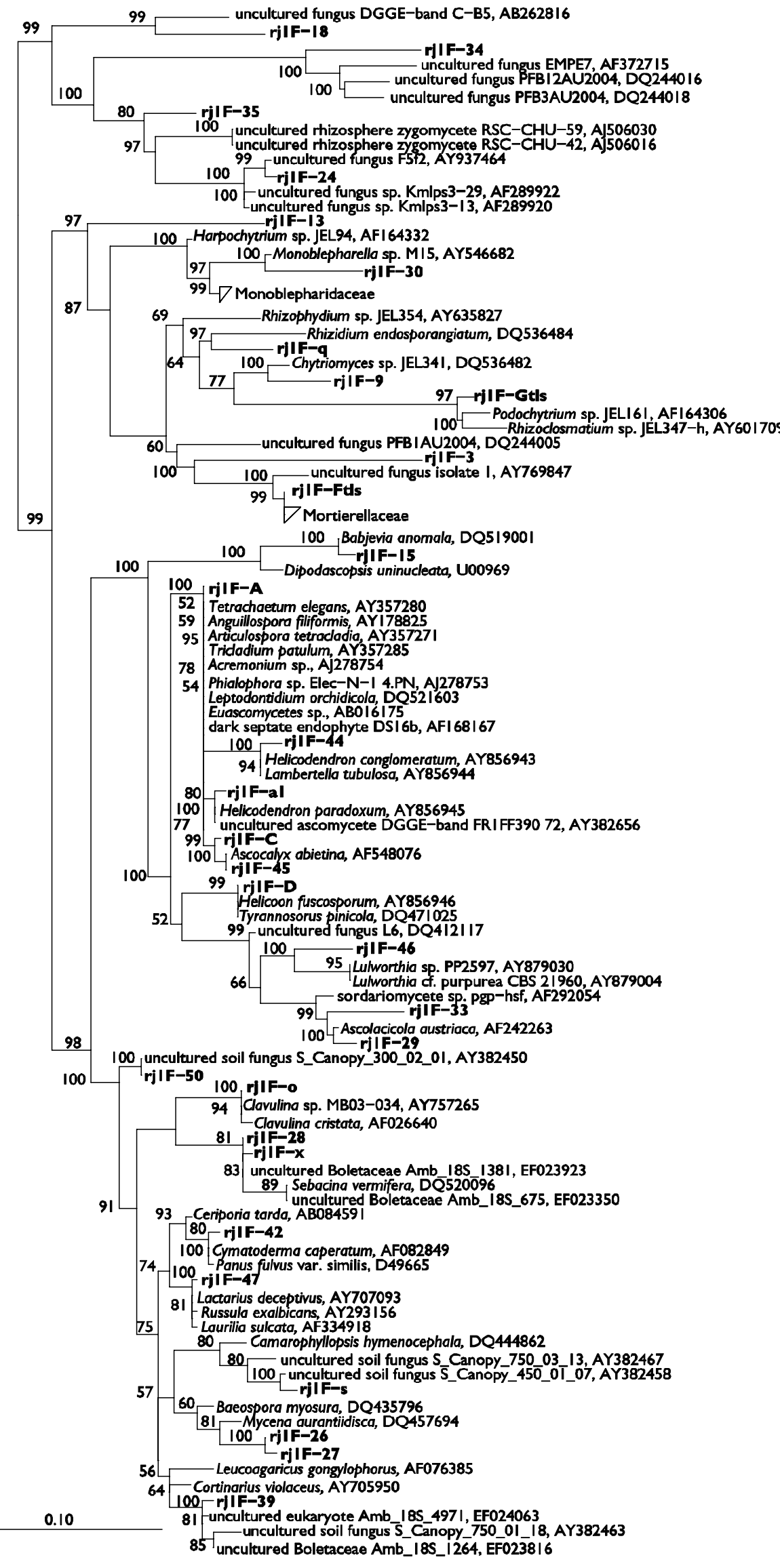

Fig. 1. ARB generated phylogenetic tree of fungal partial 18SrDNA sequences. Scale bar represents $10 \%$ dissimilarity. 


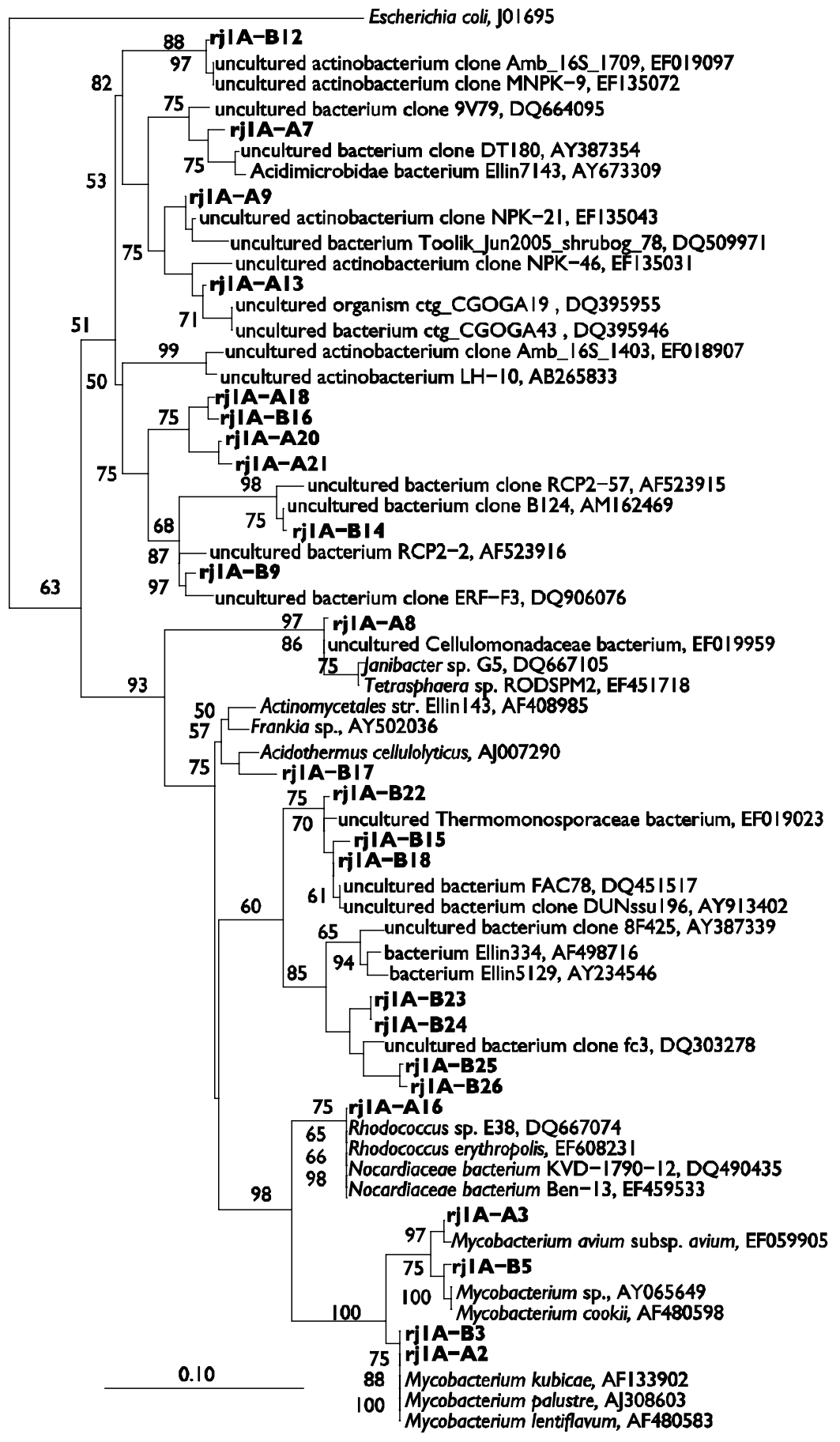

Fig. 2. ARB generated phylogenetic tree of actinobacterial partial 16SrDNA sequences. Scale bar represents $10 \%$ dissimilarity. 

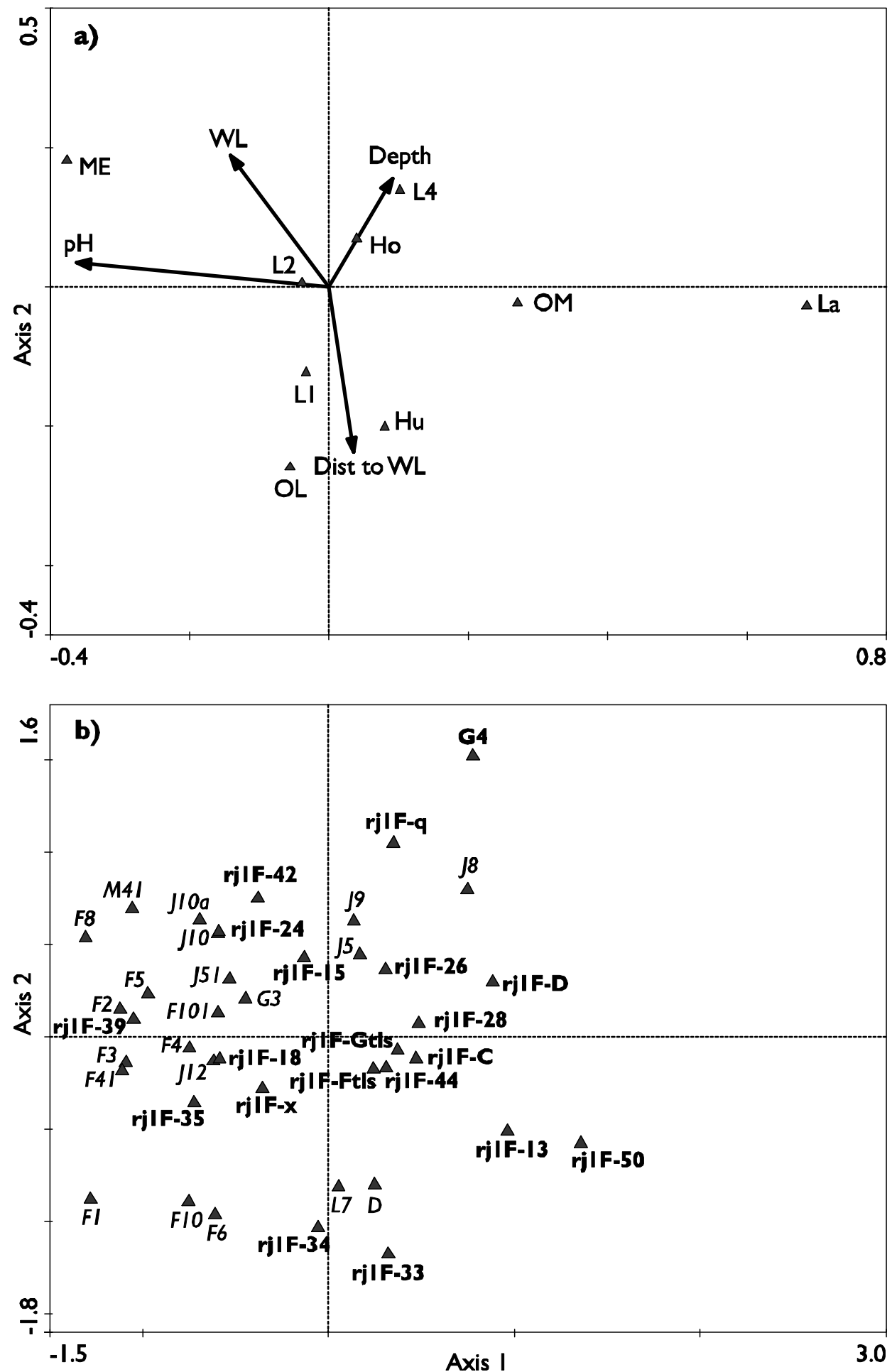

Fig. 3. Correspondence analysis (CA) of the fungal partial DGGE-derived 18SrDNA bands from the three pristine plots with different nutrient levels. a. The relation of the environmental variables to the $18 \mathrm{SrDNA}$ banding patterns. Centroids are shown for dummy variables and arrows represent continuous variables. Nutrient levels: ME, mesotrophic; OL, oligotrophic; OM, ombrotrophic. Microforms: Hu, hummock; La, lawn; Ho, hollow. Sampled layers: L1 $=0-5 \mathrm{~cm}, \mathrm{~L} 2=5-10 \mathrm{~cm}$, L4 $=20-30 \mathrm{~cm}$ from the peat surface. Depth, sampling depth ( $\mathrm{cm}$ from the peat surface; increases downwards); WL, depth of the water level (cm from the mire surface) at the time of sampling; Dist to WL; distance from the sampled layers to the water level. b. DGGE-derived partial 18SrDNA bands responsible for the separation of the samples. Included in the plot are such bands of whose variation axes 1 and 2 explained at least $10 \%$. 

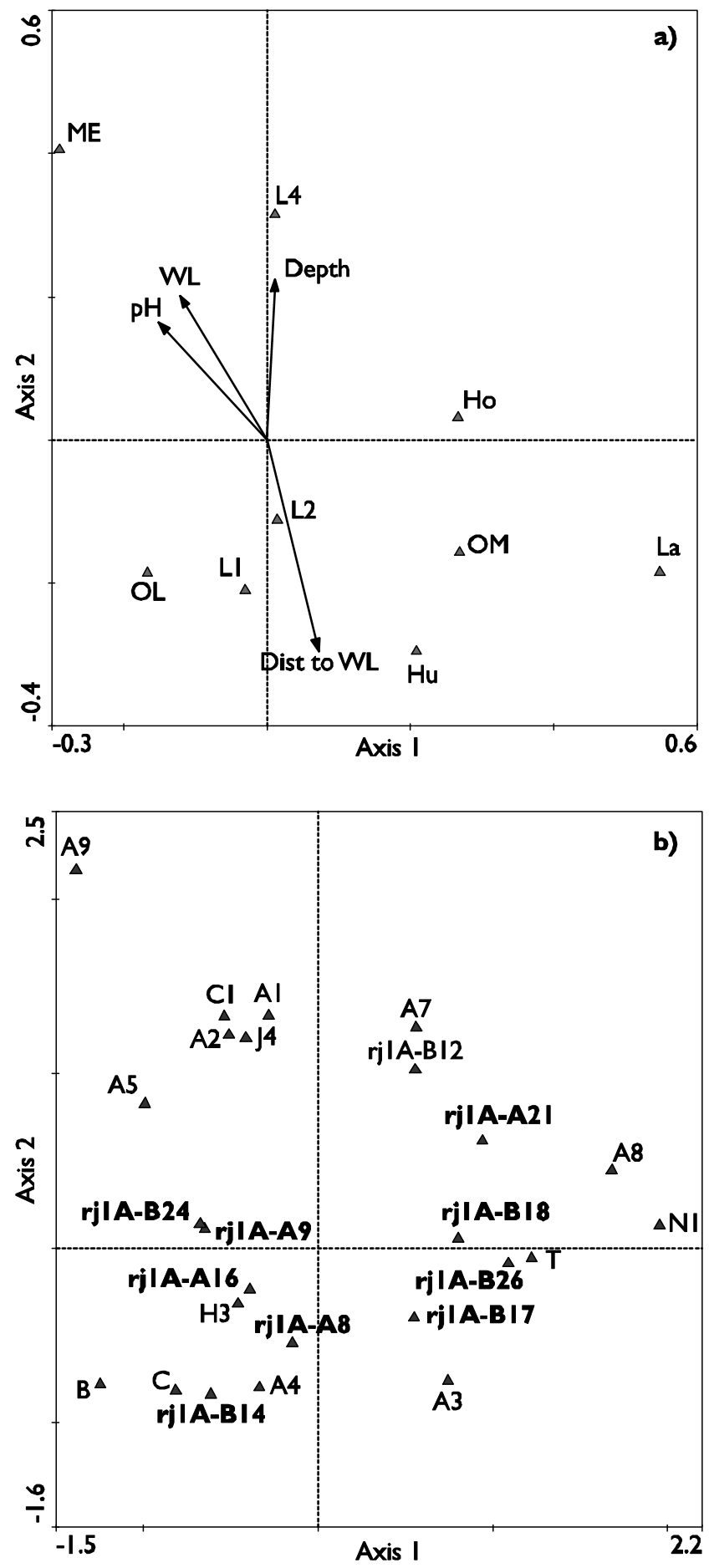

Fig. 4. Correspondence analysis (CA) of the actinobacterial partial DGGE-derived 16SrDNA bands from the three pristine sites with different nutrient levels. a. The relation of the environmental variables to the $16 \mathrm{SrDNA}$ banding patterns. Centroids are shown for dummy variables and arrows represent continuous variables. b. DGGE-derived partial 16SrDNA bands responsible for the separation of the samples. Included in the plot are such bands of whose variation axes 1 and 2 explained at least 10\%. See abbreviations in the legend of Fig 3. 

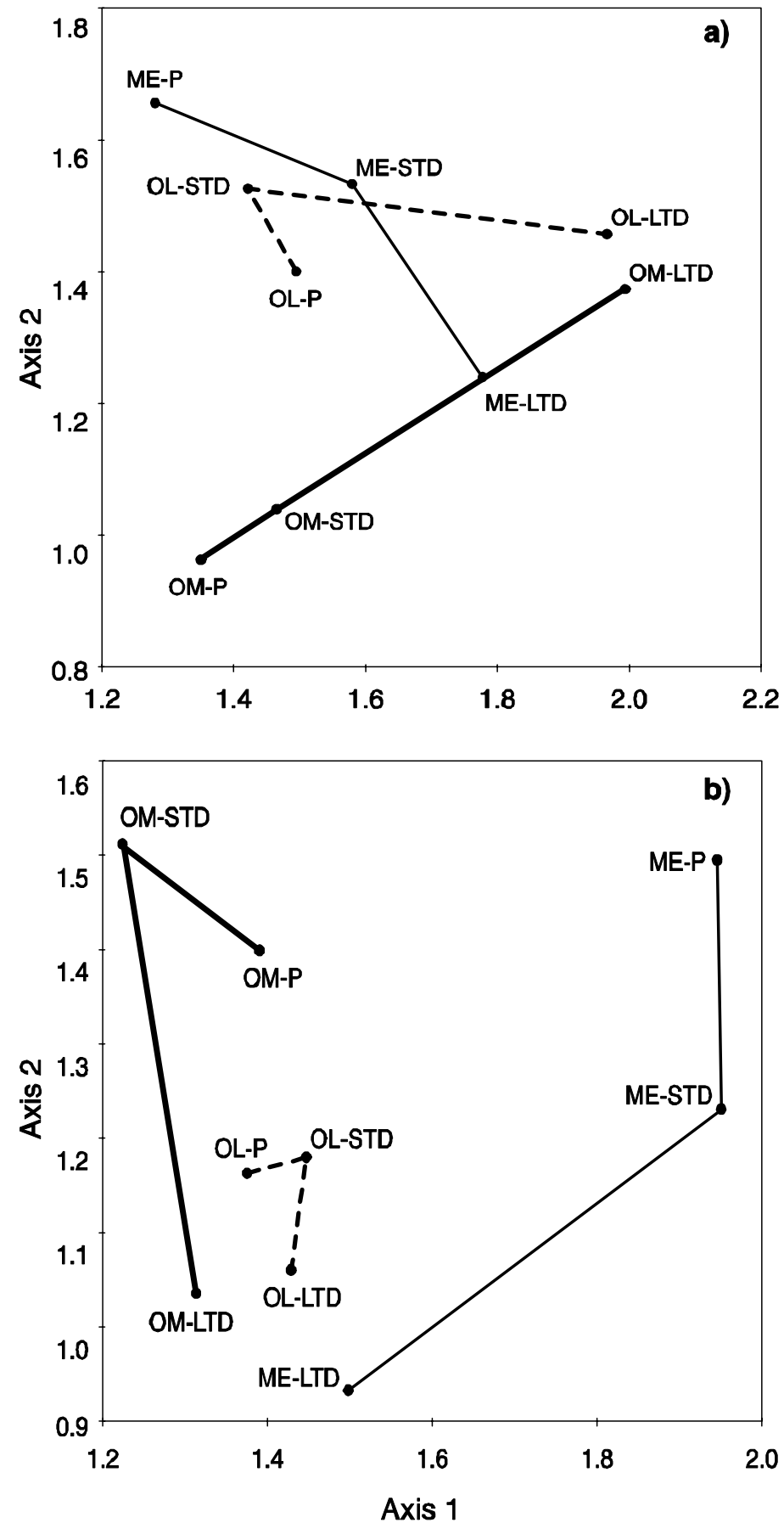

Fig. 5. Differences between the plots representing different nutrient levels and hydrological conditions based on a. CA of the fungal partial DGGE-derived 18SrDNA bands, b. CA of the actinobacterial partial DGGE-derived 16SrDNA bands. Dummy variables indicating the layers sampled were used as covariates. Nutrient levels: ME, mesotrophic; OL, oligotrophic; OM, ombrotrophic. Hydrological conditions: P, pristine; STD, short-term drainage; LTD, long-term drainage. 
Appendix A.

Fungal sequences (prefix rj1F-)

\begin{tabular}{|c|c|c|c|c|c|c|c|c|c|c|c|c|c|c|c|c|c|c|c|c|c|c|c|c|c|c|c|c|c|c|c|}
\hline \multicolumn{3}{|c|}{ Sample } & \multirow[t]{2}{*}{3} & \multirow[t]{2}{*}{9} & \multirow{2}{*}{$\begin{array}{l}\text { Ftls } \\
3\end{array}$} & \multirow{2}{*}{$\frac{\text { Gtls }}{3}$} & \multirow[t]{2}{*}{13} & \multirow{2}{*}{$\frac{15}{15}$} & \multirow{2}{*}{$\begin{array}{c}18 \\
3\end{array}$} & \multirow[t]{2}{*}{$\mathrm{q}$} & \multirow[t]{2}{*}{$\mathrm{s}$} & \multirow{2}{*}{24} & \multirow[t]{2}{*}{26} & \multirow[t]{2}{*}{28} & 29 & 30 & $\mathrm{x}$ & 33 & 34 & 35 & o & 39 & A & 42 & $\mathrm{C}$ & 44 & 45 & 46 & 47 & D & 50 \\
\hline $\mathrm{P}$ & $\mathrm{ME}$ & L1 & & & & & & & & & & & & & 2 & & 3 & 1 & 2 & 1 & & 2 & 2 & 2 & 3 & 3 & & & & & \\
\hline $\mathrm{P}$ & ME & L2 & & & 2 & 1 & & 3 & 2 & 1 & 2 & 1 & & 1 & & 1 & 1 & & & 1 & & 2 & 1 & 2 & 2 & 2 & 1 & 1 & 1 & & \\
\hline $\mathrm{P}$ & $\mathrm{ME}$ & $\mathrm{L} 4$ & & & 3 & 2 & & 3 & 2 & 2 & 2 & 2 & 2 & 1 & 2 & & 2 & & & 1 & 2 & 1 & 1 & 2 & 3 & 3 & & 1 & & & \\
\hline STD & ME & L1 & 1 & 2 & 3 & 2 & & 2 & 2 & & & 1 & 1 & 3 & & & 3 & 2 & 2 & & 1 & & 3 & 1 & 3 & 2 & 2 & & 2 & 1 & 1 \\
\hline STD & ME & L2 & & 1 & 3 & 1 & & 3 & 1 & & 1 & 1 & 1 & 2 & 1 & 2 & 2 & 1 & 2 & & 1 & & & 1 & 3 & 3 & & & 1 & & 1 \\
\hline STD & ME & $\mathrm{L} 4$ & & 1 & 3 & 2 & & 1 & & & & & & 1 & & 1 & 1 & 1 & & & & 2 & 1 & & 2 & 1 & 1 & 2 & 1 & & \\
\hline LTD & ME & $\mathrm{L} 1$ & & & 3 & 3 & & 1 & 1 & & 1 & & 3 & 2 & 1 & & & & 1 & & & 1 & & 1 & 3 & 3 & 1 & 1 & 2 & & 2 \\
\hline LTD & $\mathrm{ME}$ & L2 & & 1 & 3 & 2 & & 2 & 2 & 2 & & & 2 & 2 & 2 & 1 & & & 1 & 2 & & 2 & 1 & 1 & 3 & 2 & 1 & 1 & 1 & & 1 \\
\hline LTD & ME & L4 & & & 3 & 2 & & 1 & & & & 1 & 1 & 2 & 2 & & & & 1 & 1 & & & 1 & & 3 & 2 & 1 & 1 & & & \\
\hline $\mathrm{P}$ & OL & $\mathrm{L} 1$ & 1 & 1 & 2 & 2 & & 1 & & 1 & & & 1 & 1 & 2 & & & & 1 & & 1 & 1 & 1 & & 3 & 1 & 1 & 1 & 1 & & \\
\hline $\mathrm{P}$ & OL & L2 & & 1 & 3 & 2 & 1 & 2 & 1 & 2 & 2 & & 2 & 1 & 1 & 1 & 1 & & 3 & & 1 & 1 & 1 & & 3 & 2 & 1 & 2 & 1 & & \\
\hline $\mathrm{P}$ & OL & L4 & & & 2 & & & & & & & & & & 1 & & & & 2 & 1 & & & & & 2 & 2 & 1 & & & & 1 \\
\hline STD & $\mathrm{OL}$ & $\mathrm{L} 1$ & 1 & 1 & 3 & 2 & & 1 & 1 & & & & 1 & 1 & & & & & 1 & & 1 & 1 & 1 & & 3 & 3 & 1 & 2 & 1 & 1 & \\
\hline STD & $\mathrm{OL}$ & L2 & & 1 & 3 & & 1 & 1 & 3 & 2 & 1 & 2 & 3 & 3 & & 1 & & 1 & 2 & 1 & 3 & & 2 & 1 & 3 & 3 & 1 & 1 & & 1 & 1 \\
\hline STD & $\mathrm{OL}$ & L4 & 2 & & 2 & 1 & & & 1 & 1 & & 1 & 1 & 2 & 2 & 2 & 2 & 1 & 2 & & & 1 & 2 & & 3 & 2 & & 1 & & 2 & 1 \\
\hline LTD & OL & L1 & & & 3 & 2 & & 1 & 1 & & & & 2 & 1 & 1 & & & 1 & 2 & & 1 & & & & 3 & 3 & & 1 & 3 & & \\
\hline LTD & OL & L2 & & & 2 & 1 & 1 & & & & & & & 1 & & & & & 1 & 1 & 1 & 1 & & & 3 & 1 & 2 & 3 & 1 & & \\
\hline LTD & $\mathrm{OL}$ & $\mathrm{L} 4$ & & 1 & 2 & 1 & & 2 & & & & & & 1 & 1 & & & & 3 & & 1 & & 2 & 2 & 3 & & & 1 & 1 & 2 & \\
\hline $\mathrm{P}$ & $\mathrm{OM} \mathrm{Hu}$ & L1 & & & 2 & 2 & & 1 & 1 & & 1 & & & 1 & 1 & 1 & 2 & 1 & 2 & 2 & 1 & & 1 & & 3 & 2 & & & 1 & 1 & \\
\hline $\mathrm{P}$ & $\mathrm{OM} \mathrm{Hu}$ & L2 & & & 3 & 3 & & 1 & & & & & & 1 & & & & & 1 & 1 & 1 & & & & 3 & 2 & & & & 1 & \\
\hline $\mathrm{P}$ & $\mathrm{OM} \mathrm{Hu}$ & $\mathrm{L} 4$ & & & 2 & 3 & 1 & 2 & & 1 & & & 1 & 2 & & 1 & & & & & & & 1 & & 2 & & & 1 & & & \\
\hline $\mathrm{P}$ & OM La & L1 & & 2 & 2 & 2 & & & & 2 & & & & 1 & & & & & & & & & 1 & & 3 & 2 & 1 & & 1 & 2 & \\
\hline $\mathrm{P}$ & OM La & L2 & & 1 & 3 & 3 & & 1 & & 1 & 1 & & 1 & 2 & & & & & & & & & & 1 & 3 & 3 & 2 & & 1 & & 2 \\
\hline $\mathrm{P}$ & OM La & $\mathrm{L} 4$ & & & 3 & 2 & 1 & 1 & & & & & 2 & 1 & 1 & & 1 & & 2 & & & & 2 & & 3 & 2 & & & & & \\
\hline $\mathrm{P}$ & ОМ Но & L1 & & & 2 & 2 & 1 & 2 & 1 & 1 & & & 1 & 1 & & & 1 & 1 & & 1 & & & 1 & 1 & 2 & 2 & 1 & & & 1 & 1 \\
\hline $\mathrm{P}$ & OM Ho & L2 & & & 1 & 2 & & 1 & & 1 & 2 & & 1 & & 1 & & 1 & & 1 & & & & 2 & & 2 & 2 & 1 & 1 & & 1 & \\
\hline $\mathrm{P}$ & OM Ho & L4 & & & 1 & 1 & & 1 & & 1 & & & & & 1 & & & & & & & & & 1 & 1 & & & & & & \\
\hline STD & $\mathrm{OM} \mathrm{Hu}$ & $\mathrm{L} 1$ & 1 & 3 & 3 & 3 & 1 & & & & 1 & & 1 & 3 & & & & & 1 & 2 & & 1 & & 1 & 2 & 2 & & & & 2 & 1 \\
\hline STD & $\mathrm{OM} \mathrm{Hu}$ & L2 & & 1 & 3 & 3 & & 1 & & & & & & & 1 & & 2 & 1 & 1 & 1 & & & & & 3 & 3 & & & & & \\
\hline STD & $\mathrm{OM} \mathrm{Hu}$ & L4 & & & 2 & 3 & 1 & 1 & 1 & & & & 1 & 2 & & 1 & 1 & & & 1 & & 1 & 2 & 1 & 3 & 3 & 1 & 1 & 1 & & \\
\hline STD & OM La & L1 & & 1 & 3 & 3 & & 2 & 1 & 1 & & & & 1 & & 1 & & & 1 & 1 & 1 & & & & 3 & 3 & 1 & & & 1 & \\
\hline STD & OM La & L2 & & & 3 & 3 & & 3 & 1 & 1 & & & & 1 & 1 & 2 & & & 1 & 1 & & & & & 3 & & 1 & & & & 1 \\
\hline STD & OM La & L4 & & & 3 & 3 & & 1 & 1 & & & & & 2 & 1 & & & & 1 & & & & 1 & 1 & 1 & 2 & & & & & \\
\hline STD & OM Ho & L1 & & & 3 & 3 & & 1 & & 1 & 1 & & 3 & 3 & 1 & & & 1 & 3 & 2 & & & & 1 & 3 & 2 & & 3 & & 1 & \\
\hline STD & OM Ho & L2 & & 1 & 3 & 2 & 1 & 1 & 2 & 2 & & & & 2 & & 2 & & & 3 & 1 & & 1 & & 1 & 2 & 3 & & & & & \\
\hline STD & OM Ho & $\mathrm{L} 4$ & 1 & & 1 & 1 & & & & & 1 & & 1 & & & 1 & 1 & & & & & & & & & & & & & & \\
\hline LTD & $\mathrm{OM}$ & L1 & & 1 & 3 & 3 & 1 & 2 & & & & & & 1 & & 1 & & & 1 & & & 1 & 1 & 1 & 2 & 1 & 2 & & & & \\
\hline LTD & $\mathrm{OM}$ & L2 & & 2 & 3 & 3 & 2 & 1 & & & & & 1 & & 3 & & & & & & & 1 & 2 & 2 & 1 & 2 & 2 & 1 & & 1 & \\
\hline LTD & $\mathrm{OM}$ & $\mathrm{L} 4$ & & & 1 & 2 & 1 & 1 & 1 & & & & 1 & & & & & 1 & 1 & 1 & & & & & 2 & 1 & 1 & 1 & 1 & & 1 \\
\hline
\end{tabular}


Actinobacterial sequences (prefix rj1A-)

\begin{tabular}{|c|c|c|c|c|c|c|c|c|c|c|c|c|c|c|c|c|c|c|c|c|c|c|c|c|}
\hline \multicolumn{3}{|c|}{$\overline{\text { Sample }}$} & \multirow{2}{*}{ B3 } & \multirow{2}{*}{$\mathrm{A} 2$} & \multirow{2}{*}{$\begin{array}{l}\mathrm{A} 3 \\
2\end{array}$} & \multirow[t]{2}{*}{ A7 } & \multirow{2}{*}{$\begin{array}{l}\mathrm{A} 8 \\
1\end{array}$} & \multirow{2}{*}{$\begin{array}{l}\text { A9 } \\
2\end{array}$} & \multirow{2}{*}{ B9 } & \multirow{2}{*}{$\begin{array}{l}\mathrm{A} 13 \\
2\end{array}$} & B12 & \multirow{2}{*}{ A16 } & \multirow{2}{*}{$\begin{array}{l}\mathrm{B} 14 \\
\end{array}$} & B16 & B15 & B17 & \multirow{2}{*}{ A18 } & \multirow{2}{*}{$\begin{array}{l}\mathrm{B} 18 \\
2\end{array}$} & $\mathrm{~A} 20$ & $\mathrm{~A} 21$ & B23 & B24 & B25 & B26 \\
\hline $\mathrm{P}$ & ME & L1 & & & & & & & & & & & & & & 2 & & & 2 & & & 2 & & 1 \\
\hline $\mathrm{P}$ & $\mathrm{ME}$ & L2 & & 1 & 3 & & 1 & 2 & 2 & 1 & 3 & 3 & & 1 & 1 & 1 & & & & & 1 & 3 & & \\
\hline $\mathrm{P}$ & $\mathrm{ME}$ & L4 & & & 3 & & & 2 & 2 & 1 & 1 & 2 & & 1 & & & & & & 1 & 1 & 1 & & \\
\hline STD & $\mathrm{ME}$ & L1 & 1 & & 3 & 1 & 1 & 3 & 3 & 2 & 2 & 3 & & 1 & & 2 & & & & & & 1 & & 1 \\
\hline STD & $\mathrm{ME}$ & $\mathrm{L} 2$ & & & 2 & & 2 & 2 & 2 & & 1 & 2 & 2 & 2 & 1 & & & & 1 & & 1 & 2 & & \\
\hline STD & $\mathrm{ME}$ & L4 & & & 2 & & 1 & & & & 1 & 2 & & & & 1 & & & & & & & & \\
\hline LTD & ME & L1 & & & 2 & 1 & & & 2 & 2 & & 1 & 1 & & & 2 & 1 & & & 1 & 1 & & & 2 \\
\hline LTD & $\mathrm{ME}$ & L2 & 2 & & 3 & & & & 1 & & 1 & & & & & 1 & & 1 & 3 & & & & & \\
\hline LTD & $\mathrm{ME}$ & L4 & & 1 & 3 & & & 1 & 1 & 1 & & 3 & & & & & & & & & & & & \\
\hline $\mathrm{P}$ & $\mathrm{OL}$ & L1 & 2 & & 2 & & 1 & 1 & 2 & 2 & & 2 & 1 & & & 2 & & & & & & & & \\
\hline $\mathrm{P}$ & $\mathrm{OL}$ & L2 & 1 & & 3 & 1 & 2 & 3 & 3 & 2 & & 3 & & & & 2 & & 1 & 1 & 1 & 1 & 2 & 1 & \\
\hline $\mathrm{P}$ & $\mathrm{OL}$ & L4 & 1 & & 3 & 1 & & & 1 & 1 & 1 & 1 & 1 & & & & & & 1 & 2 & 1 & & & 1 \\
\hline STD & OL & L1 & 2 & & 3 & & & & 3 & 3 & 3 & 3 & & & & 2 & & & & & & 2 & & 1 \\
\hline STD & $\mathrm{OL}$ & L2 & 3 & & 3 & 1 & & 1 & 3 & 2 & 1 & 3 & & & & 2 & 1 & & 1 & & 1 & 2 & & 1 \\
\hline STD & $\mathrm{OL}$ & L4 & 2 & 1 & 3 & 1 & & 1 & 1 & 3 & & 2 & 1 & & & & & & & 1 & 1 & & & 1 \\
\hline LTD & $\mathrm{OL}$ & L1 & 3 & 1 & 3 & & 1 & & 3 & 2 & & 1 & & 1 & & 3 & & & 2 & & 1 & & 1 & 2 \\
\hline LTD & $\mathrm{OL}$ & L2 & 2 & 2 & 3 & & & 1 & & 1 & 2 & 2 & 1 & & 1 & 2 & & 1 & 2 & & & 3 & & 2 \\
\hline LTD & $\mathrm{OL}$ & L4 & 2 & 1 & 3 & 1 & 2 & 2 & 1 & 3 & 2 & 2 & & & & & & 3 & 1 & 1 & & & & 2 \\
\hline $\mathrm{P}$ & $\mathrm{OM} \mathrm{Hu}$ & L1 & & & 3 & & & 1 & 3 & & & 2 & 1 & & & 1 & 1 & & & & & 1 & 1 & 1 \\
\hline $\mathrm{P}$ & $\mathrm{OM} \mathrm{Hu}$ & L2 & 1 & & 2 & & & & 1 & & & 1 & 1 & 1 & & 2 & & & & 1 & 1 & & & 2 \\
\hline $\mathrm{P}$ & OM Hu & L4 & & & & & 2 & & 1 & & 1 & 2 & & & 1 & 2 & 1 & & 2 & & & & & 1 \\
\hline $\mathrm{P}$ & $\mathrm{OM} \mathrm{La}$ & L1 & & & 1 & & & & 2 & & & 1 & & & & 2 & & & & & & & & \\
\hline $\mathrm{P}$ & OM La & L2 & & & 2 & & & & 2 & 2 & & 1 & & & 1 & 2 & 1 & 2 & & & & & & 2 \\
\hline $\mathrm{P}$ & OM La & L4 & & & 2 & & & & & & 1 & 2 & & & & 1 & & & & & 1 & & & \\
\hline $\mathrm{P}$ & OM Ho & L1 & & 1 & 2 & & & & 3 & 1 & 2 & & & & & 1 & 1 & 1 & 1 & 1 & & & & \\
\hline $\mathrm{P}$ & OM Ho & L2 & & 1 & 1 & & & & 1 & & 1 & & & & & 2 & & 1 & & & & & & 1 \\
\hline $\mathrm{P}$ & OM Ho & L4 & 1 & & 3 & 1 & & & & 1 & & 2 & 1 & 2 & 1 & 1 & & & & 1 & 2 & & & \\
\hline STD & $\mathrm{OM} \mathrm{Hu}$ & $\begin{array}{l}\text { L4 } \\
\text { L1 }\end{array}$ & & 2 & 2 & & 1 & & 3 & & 2 & 1 & 1 & & & 1 & 1 & & & 1 & & & & 3 \\
\hline STD & $\mathrm{OM} \mathrm{Hu}$ & L2 & 2 & & 2 & & & & 3 & 1 & & 1 & 1 & 1 & 1 & 3 & 1 & & & & & & & 2 \\
\hline STD & $\mathrm{OM} \mathrm{Hu}$ & L4 & & & 2 & 1 & 2 & 1 & & 1 & 1 & & 1 & 1 & & 1 & & 1 & 1 & 2 & & & & \\
\hline STD & OM La & L1 & & & 2 & 1 & 1 & & 2 & & 1 & & & & & 2 & & & & & & & & 2 \\
\hline STD & OM La & L2 & & 1 & 3 & & 1 & & 3 & 1 & 1 & 2 & & & & 2 & 1 & 3 & 1 & 1 & 1 & 1 & & 3 \\
\hline STD & OM La & L4 & & & 2 & 1 & & & & 1 & & & & 1 & & & & & & 1 & 1 & & & \\
\hline STD & OM Ho & L1 & & & 2 & & & & 3 & 3 & & 1 & 1 & 3 & & 3 & 1 & & & 1 & & & & 1 \\
\hline STD & ОМ Но & L2 & & & 2 & 1 & & & 1 & 1 & 1 & & & & & 2 & & 1 & 1 & 2 & & & & \\
\hline STD & OM Ho & L4 & & 2 & 3 & 2 & 1 & 1 & & & & 2 & & & & 3 & 1 & & 1 & 2 & 1 & 1 & & \\
\hline LTD & $\mathrm{OM}$ & L1 & 2 & & 3 & & & & 3 & 1 & & 1 & 1 & 1 & & 2 & & & 2 & 1 & & & 1 & 1 \\
\hline LTD & OM & L2 & & 1 & 3 & & 1 & 2 & 3 & 3 & 1 & 2 & & 1 & 2 & 3 & & & 3 & 1 & & & 1 & 2 \\
\hline LTD & $\mathrm{OM}$ & L4 & 1 & 1 & 2 & & & & & & 1 & & 2 & & & 2 & & & & & 1 & 1 & & \\
\hline
\end{tabular}

